OPEN ACCESS

Edited by:

Toshiyuki Murai,

Osaka University, Japan

Reviewed by:

Thomas N. Wight,

Benaroya Research Institute,

United States

Paul Laszlo Bollyky,

Stanford University, United States

*Correspondence:

Lilly Y. W. Bourguignon

lilly.bourguignon@ucsf.edu

Specialty section:

This article was submitted to Cancer Immunity and Immunotherapy,

a section of the journal

Frontiers in Oncology

Received: 14 March 2019

Accepted: 24 May 2019

Published: 21 June 2019

Citation:

Bourguignon LYW (2019) Matrix Hyaluronan-CD44 Interaction Activates MicroRNA and LncRNA

Signaling Associated With Chemoresistance, Invasion, and

Tumor Progression.

Front. Oncol. 9:492.

doi: 10.3389/fonc.2019.00492

\section{Matrix Hyaluronan-CD44 Interaction Activates MicroRNA and LncRNA Signaling Associated With Chemoresistance, Invasion, and Tumor Progression}

\author{
Lilly Y. W. Bourguignon*
}

Endocrine Unit (111N2), Department of Medicine, San Francisco Veterans Affairs Medical Center, University of California, San Francisco, San Francisco, CA, United States

Tumor malignancies involve cancer cell growth, issue invasion, metastasis and often drug resistance. A great deal of effort has been placed on searching for unique molecule(s) overexpressed in cancer cells that correlate(s) with tumor cell-specific behaviors. Hyaluronan (HA), one of the major ECM (extracellular matrix) components have been identified as a physiological ligand for surface CD44 isoforms which are frequently overexpressed in malignant tumor cells during cancer progression. The binding interaction between HA and CD44 isoforms often stimulates aberrant cellular signaling processes and appears to be responsible for the induction of multiple oncogenic events required for cancer-specific phenotypes and behaviors. In recent years, both microRNAs (miRNAs) (with 20-25 nucleotides) and long non-coding RNAs (IncRNAs) (with 200 nucleotides) have been found to be abnormally expressed in cancer cells and actively participate in numerous oncogenic signaling events needed for tumor cell-specific functions. In this review, I plan to place a special emphasis on HA/CD44-induced signaling pathways and the presence of several novel miRNAs (e.g., miR-10b/miR-302/miR-21) and IncRNAs (e.g., UCA1) together with their target functions (e.g., tumor cell migration, invasion, and chemoresistance) during cancer development and progression. I believe that important information can be obtained from these studies on HA/CD44-activated miRNAs and IncRNA that may be very valuable for the future development of innovative therapeutic drugs for the treatment of matrix HA/CD44-mediated cancers.

Keywords: hyaluronan (HA), CD44, miRNAs, LncRNA UCA1, chemoresistance, invasion, tumor progression

\section{INTRODUCTION}

Cancer cells are known to display dysregulated signaling pathways which are responsible for abnormal cellular functions (1-3). Myriad studies have attempted to understand the cellular and molecular mechanisms involved in the onset of tumor cell-specific behaviors (e.g., tumor cell migration, invasion, survival, and chemoresistance). Interactions between matrix hyaluronan (HA), the major glycosaminoglycan component of extracellular matrix (ECM), and variant 
isoforms of CD44 (HA receptor) have been shown to be tightly linked to the development of aberrant signaling events in a variety of cancers $(4,5,5-30)$. It is known that HA binding to certain isoforms of CD44 selectively activates multiple oncogenic signaling pathways leading to tumor cell-specific phenotypes $(4,5,5-30)$. HA is also present in different sizes (e.g., large vs. small sizes) $(4,5,5-28)$. The binding interaction between large size HA-CD44 and small size HA-CD44 may cause selective activation of downstream effector functions in cancer stem cells (31-35). Furthermore, recent studies indicate that HA-CD44 interaction stimulates the expression of specific microRNAs (miRNAs) and coordinates downstream, intracellular signaling pathways that influence multiple tumor cell-specific functions (31-35). This review focuses first on matrix HA interaction with CD44 in regulating cancer cell signaling pathways, and then describes downstream target functions of these signaling events that contribute to tumor initiation, migration, invasion, chemoresistance, and tumor progression. We believe that this new information could establish the ground work for developing novel therapeutic agents that would effectively target HA/CD44activated signaling events and specific downstream target molecules/functions in tumor cells-thus providing important new cancer therapies.

\section{MATRIX HYALURONAN (HA) IN CANCERS}

It has been well accepted fact that unique oncogenesis-induced migration, invasion and metastasis of tumor cells play key roles in causing morbidity in patients (1-3). Many studies have searched for unique molecules which are frequently expressed by cancer cells which correlate with tumor-specific properties. Matrix hyaluronan (HA) known to consist of both $\mathrm{D}$-glucuronic acid and $\mathrm{N}$-acetyl-D-glucosamine in a form of repeating disaccharide units in the extracellular matrix (ECM) (4-7) has been recognized as one of the important contributors in causing tumor development and progression $(5,8-11)$. It is welldocumented that HA is first made by two precursor molecules, uridine diphosphate-glucuronic acid (UDP-GlcA) and uridine diphosphate $\mathrm{N}$-acetylglucosamine (UDP-GlcNAc) through the regulation of HAS1, HAS2, and HAS3 (also known as HA synthase enzymes) inside of the cells and then becomes secreted into the external environment (outside of the cells) as one of the major ECM components in both normal and malignant cells (Figure 1). Generation of large sizes of HA polymers (>2-3 $\times 10^{6}$ Daltons) often requires HAS1 and HAS2, whereas the production of smaller-size of HA $\left(<1-2 \times 10^{5}\right.$ Daltons) appears to rely on HAS3 (8-10). A few oncogenic signaling events have been shown to be involved in the unusual activities of HAS1, HAS2, and HAS3 and cause aberrant synthesis and production of HA which then promotes changes of cellular functions and onset of malignant transformation and cancer development (8-10). Large sizes of HA often can be degraded into many biologically active mid-sized and/or small-sized fragments by hyaluronidases such as Hyal-1, Hyal-2, or PH20/Spam1 (11). Most importantly, the level of HA appears to be elevated at the contact region between cancer cells and extracellular matrix (ECM) which

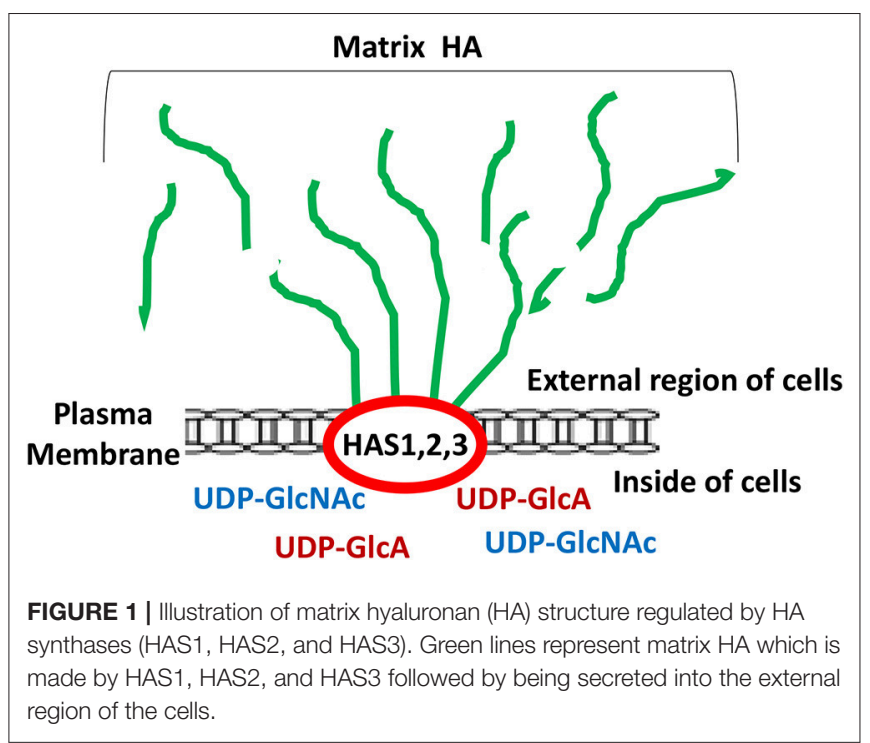

may be responsible for the induction of cancer cell-associated properties (5). Thus, over production of HA may be used as a predictor of cancer development.

It has been well documented that HA promotes a variety of oncogenic signaling pathways and causes abnormal physiological changes in cancer cells. For example, HA activates PI3K-AKT signaling pathway which is known to be responsible for tumor cell proliferation, glucose metabolism, cytokine production, angiogenesis and survival $(36,37)$. Overproduction of HA often induces certain metabolic changes such as accelerating the hexosamine biosynthetic pathway and glycolysis process in breast cancer cells (38). There is also growing evidence that treatment of cancer cells with HA upregulates the expression of the multidrug transporter, MDR1 (P-glycoprotein), and ABC drug transporters (ABCB3, $\mathrm{ABCC} 1, \mathrm{ABCC} 2$, and $\mathrm{ABCC} 3$ ) leading to aberrant drug fluxes and chemoresistance in breast and ovarian cancer cells $(39,40)$. Most importantly, HA activates cytoskeleton regulators such as RhoGTPases (e.g., Rho, Rac, and Cdc42) which are known to regulate tumor cell migration, and invasion (41). Additionally, HA is capable of upregulating Rho-kinase activities which in turn stimulates 1,4,5-triphosphate (IP3)-mediated $\mathrm{Ca} 2+$ fluxes and endothelial cell migration-a required step for angiogenesis $(42,43)$. Moreover, certain sizes of low molecular weight hyaluronan appears to induce angiogenesis involving Cdc42 signaling (44). Thus, these findings suggest that abnormal HA-mediated signaling processes may play a critical role in regulating tumor cell-specific properties. To further dissect the cellular and molecular mechanisms involved in HAmediated oncogenesis, we decided to focus on the interaction between $\mathrm{HA}$ and its binding receptor, CD44, in a variety of cancer cells as described below.

\section{CD44 IN CANCERS}

HA binding receptor, CD44 is a transmembrane glycoprotein and has been detected in both normal and tumor cells (12-16). 
Importantly, upregulation of CD44 is often closely associated with abnormal tumor cell behaviors (e.g., proliferation, survival, migration/invasion, and chemoresistance) (13-15). Based on the results from nucleotide sequence analyses, CD44 appears to be encoded by a single gene with 19 exons and exhibits in many different isoforms $(16,17)$. For example, CD44s (so-called CD44 standard form), contains exons $1-5$ at the $\mathrm{N}$-terminal region (with HA binding sites), exons 15-16 at the membrane proximal area and exon 17 at the transmembrane region, as well as exons 18-19 at C-terminal region (with signaling regulation capacity) (Figure 2). CD44 is also known to undergo alternative spicing processes $(16,17)$. Potentially, the alternative splicing events can occur at 12 exons (out of the 19 exons). Frequently, it has been observed that different exons become inserted at the external region near the membrane proximal domain (between exon 614 or v1-v10) of CD44 $(16,17)$ (Figure 2). For example, exons 12 (v8), 13 (v9), and 14 (v10) are inserted into the CD44s transcripts in epithelial cells $(18,19)$. Additional exon 7-14 (v3-v10) and exon 14 (v10) have been found to be inserted into the CD44s transcript in keratinocytes and endothelial cells, respectively $(20,21)$ and these isoforms have been designated as CD44v10 and CD44v3-10 $(20,21)$ (Figure 2). Most of these CD44 variant $(\mathrm{CD} 44 \mathrm{v})$ isoforms share similar HA binding capacity at the $\mathrm{N}$-terminal region of CD44 (exon 1-5) and a transmembrane domain (exon 17) as well as a signaling interactive region at the cytoplasmic site (exon 18-19). The differences of CD44v isoforms appear to occur at the membrane proximal region (exon 6-14) of the CD44 molecules. A variety of unique CD44 isoforms have been detected in cancer cells and tumor samples (18, 22-28). Thus, selective expression of CD44v isoforms may be considered as a useful bio-marker for the detection of a variety of cancers $(18,22-28)$.

CD44 isoforms have also been detected in cancer stem cells (CSCs) which appear to display unique ability to initiate tumor cell-specific properties (29-33). For example, tumor cells with high expression of CD44 (but not cells with low CD44 expression) have been shown to induce the formation of tumors in animals with a small numbers of tumor cell injection $(29,30)$. In head and neck cancer, tumors also contain a cell subpopulation characterized by a high level of CD44v3 expression $(29,30)$. Furthermore, injection of cells with a high level of CD44v3 expression into immunodeficient mice has been shown to induce multiple types of phenotypically distinct cells, resulting in heterogeneous tumors (31-33). Thus, CD44 isoforms may be used as an important tumor marker for the detection of CSCs. Most importantly, HA-CD44 interaction stimulates CSC downstream signaling processes leading to cancer cell properties and tumor progression $(14,15,19,31-33,35,36)$.

A previous study found that CD44 is frequently located in specialized microdomains in the plasma membrane, socalled lipid rafts of cancer cells (45). The binding of HA to CD44 recruits $\mathrm{Na}+-\mathrm{H}+$ exchanger (NHE1) and Hyal-2 into CD44-containing lipid rafts, leading to both intracellular and extracellular acidification, HA modification, cathepsin B activation, and breast tumor cell invasion (i). In endothelial cells CD44v10 also interacts with the membrane-associated cytoskeletal protein, ankyrin and an intracellular calcium channel

\section{CD44 Gene}

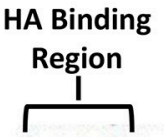

Signaling Protein

Binding Region

12345 | 678910111213141516171819

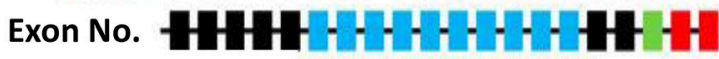

'v1 v2 v3 v4 v5 v6 v7 v8 v9 v10 TM

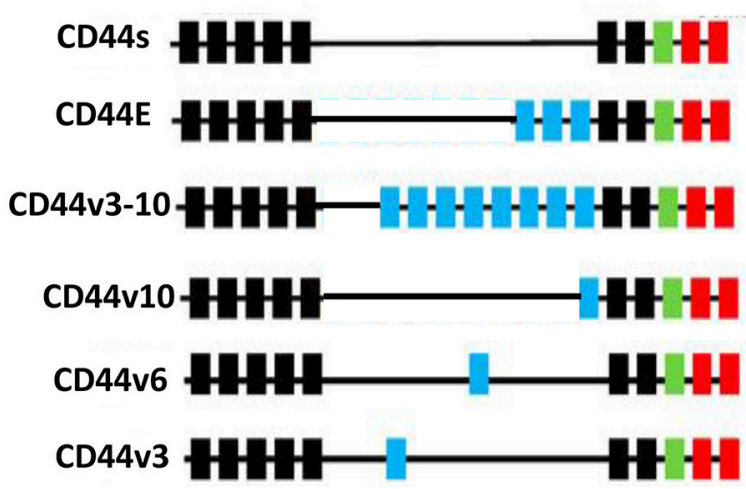

FIGURE 2 | lllustration of CD44 gene, CD44s (the standard form) and alternative spliced variants (CD44E, CD44v3-10, CD44v10, CD44v6, and CD44v3 isoforms). The HA binding domain is located at the external ( $\mathrm{N}$-terminal exon 1-5) region of all CD44 isoforms and the signaling protein binding sites are located at the cytoplasmic domain (exon 18-19) of CD44 isoforms. All isoforms contain a transmembrane domain (TM) (exon 17).

IP3 receptor in the lipid raft (43). These events result in endothelial cell adhesion and proliferation (43). Another study indicated that HA binding to CD44 promotes recruitment of adaptor and/or linker molecules with CD44 in cancer cells. For example, HA induces CD44v3-Vav2 (a guanine nucleotide exchange factor) and Grb2-p185(HER2) complex formation which then causes the co-activation of both Racl and Ras signaling leading to the concomitant onset of tumor cell growth and migration required for ovarian tumor progression (46). In addition, HA induces CD44 interaction with a RhoAspecific guanine nucleotide exchange factor (leukemia-associated RhoGEF (LARG) in human head and neck squamous carcinoma cells (47). This event results in Rho/Ras co-activation leading to PLC epsilon-Ca2+ signaling, and Raf/ERK up-regulation required for CaMKII-mediated cytoskeleton function in head and neck squamous cell carcinoma progression (47). Moreover, HA stimulates CD44 interaction with the transforming growth factor beta (TGF-beta) receptors (a family of serine/threonine kinase membrane receptors) in human metastatic breast tumor cells (MDA-MB-231 cell line). This interaction promotes activation of multiple signaling pathways leading to membranecytoskeleton interaction, tumor cell migration, and important oncogenic events (e.g., Smad2/Smad3 phosphor and PTH$\mathrm{rP}$ production) during $\mathrm{HA}$ and TGF-beta-mediated metastatic breast tumor progression (48). Additionally, it has been observed that HA induces CD44 interaction with RHAMM (receptor of 
HA-mediated motility) and causes cell motility, increased wound healing, and modification of signal transduction of the Ras signaling cascade (49-51). Furthermore, there is a report showing low molecular weight HA induces CD44 interaction with toll-like receptors. This signaling event then promotes the actin filamentassociated protein 110-actin binding and MyD88-NFKB signaling resulting in proinflammatory cytokine/chemokine production and breast tumor invasion (52). Together these findings strongly suggest that the interaction between HA/CD44 and a variety of different membrane proteins and/or regulatory molecules plays a pivotal role in regulating solid tumor cancer progression.

\section{HA-CD44 INTERACTION IN PROMOTING MICRORNA SIGNALING AND TUMOR PROGRESSION}

A class of 21-25 nucleotide length small RNAs, so called microRNAs (or miRNAs) have been shown to be involved in gene regulation (53). Overall, the impact of miRNA-regulated gene expression appears to be significant since specific miRNAs may influence the downstream effector gene expression and functions (53). For example, at least four miRNA clusters, such as let-7a-d, let-7i, miR-15b-16-2, and miR-106b-25, have been identified as being involved in G1-S transition (54) during cell cycle progression and tumor progression $(55,56)$. Moreover, dysregulation of certain miRNAs appears to be associated with a variety of cancers $(57,58)$. For example, miR-21 was first discovered as an oncomiRNA due to its universal overexpression in a variety of cancers $(57,58)$. Aberrant biosynthetic process of miRNAs (e.g., miR-21) has also been shown to be involved in the production of oncomiRNAs $(58,59)$. In addition, miRNA genes are frequently subjected to epigenetic changes in cancer leading to tumor progression (56). Furthermore, using a systematic miRNA inhibitor treatment technique on cancer cells, Ma et al discovered miR-10b overexpression which is required for tumor migration and invasion in metastatic breast cancer cells (60). Interestingly, unique miRNA such as miR-302 appears to play a key role in the maintenance of stemness properties in normal stem cells and in cancer stem cells (61). Aside from the abnormal biosynthetic processes and epigenetic modifications of miRNA genes, it has become apparent recently that tight interactions between certain miRNAs and transcription factormediated regulatory circuits may also influence important biological outcomes and drives cellular transformation $(57,58)$. Nevertheless, the abnormal signaling pathways responsible for the onset of oncogenic miRNAs during cancer development and progression remains poorly understood. In this review article, I plan to focus on several HA-CD44 interaction-induced oncogenic signaling pathways that regulate several miRNAs and downstream effector functions in a variety of cancer cells during tumor progression.

\section{Regulation of miR-21 Signaling by HA-CD44 Interaction in Cancers}

Upregulation of miR-21 has been detected in tumors and to a lesser extent in normal tissues $(58,59)$. In recent years, miR-21 has received a great of attention due to the discovery of its specific targets and functional involvement in cancer progression $(62,63)$. For example, the gene expression of program cell death (PDCD4, a tumor suppressor protein) can be blocked by miR-21 $(62,63)$. This miR-21-medited downregulation of PDCD4 results in tumor progression (62-64). Therefore, miR-21 can be viewed as a cancer cell activator. During HA/CD44 signaling, miR-21 has also been suggested to regulate tumor cell proliferation, invasion, survival, chemoresistance and tumor progression (19, 62-67). The oncogenic signaling pathways involved in the regulation of miR-21 and its function by HA-CD44 interaction in solid tumor cancers are described below:

\section{The Expression of miR-21 and Nanog-DROSHA-p68 Signaling}

Several reports showed that the interaction between RNase III DROSHA/RNA helicase p68 (DROSHA/p68) and other regulatory molecules plays an important role in regulating the biogenesis of miRNAs (68). It has been shown that p53 and the DROSHA form complexes with the RNA helicases (p68/p72) during miRNA production in HCT116 cells (68). It is also documented that TGF $\beta$-mediated SMAD-2 signaling promotes miR-21 expression (69). Specifically, DROSHA-p68 complex promotes the biogenesis of miR-21 by converting pri-miR-21 into pre-miR-21 during TGF $\beta$-specific SMAD signaling events (69). Thus, it is apparent that the production of miR-21 is closely regulated by the DROSHA/p68 microprocessor complex during cellular signaling.

HA/CD44 activated stem cell marker (Nanog) signaling pathways are also involved in regulating miR-21 expression in both breast and head and neck cancer cell lines (19, 65-67). For example, HA binding to CD44 promotes Nanog association with DROSHA/p68 microprocessor complex resulting in the upregulation of miR-21 and downregulation of PDCD4 (a tumor suppressor protein) in cancer cells. Consequently, several inhibitors of apoptosis proteins (IAPs) (e.g., c-IAP-1, cIAP-2, and XIAP) are also upregulated resulting in anti-apoptosis and chemotherapy resistance (Figure 3A). The knowledge obtained from this biogenesis study of miR-21 regulated by NanogDROSHA-p68 complexes may provide useful foundation for designing new drug target to downregulate miR-21 and increase tumor cell death and enhance chemosensitivity for the treatment of HA/CD44-mediated cancer.

\section{The Expression of miR-21 and Nanog-Stat-3 Signaling}

Abnormal Stat-3 signaling are well-known to play important roles in oncogenesis (70). Constitutively activated Stat-3 has been closely associated with human malignancies (46). It has been shown that Nanog and Stat-3 are functionally coupled in many cancer cells (39) (Figure 3A). For example, HA binding to CD44 induces a physical association between Nanog and Stat3 in head and neck cancer cells leading to miRNA-21 gene expression and production (66). Most importantly, treatments of cancer cells with several signaling perturbation agents such as Nanog siRNA or Stat-3siRNA or an anti-miR-21 inhibitor 


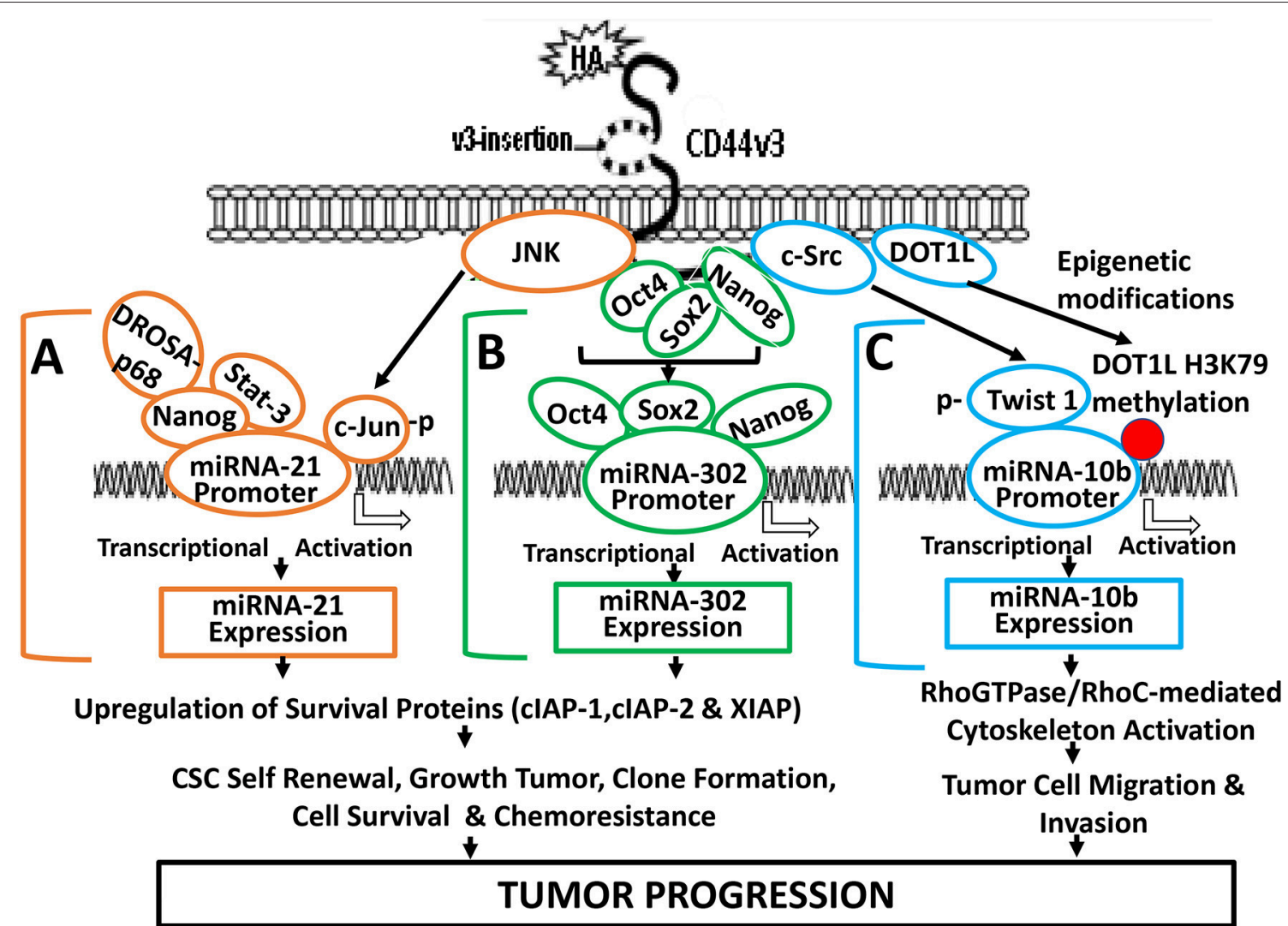

FIGURE 3 | A proposed model for HA-CD44-mediated signaling activation in the regulation of miRNA-21, miR-302, and miR-10b production and oncogenesis in tumor cells. (A) The binding of HA to CD44 promotes JNK activity which, in turn, causes phosphorylation of c-Jun. Phosphorylated c-Jun then binds to the miR-21 promoter and induces miR-21 expression. HA binding to CD44 also causes Nanog interaction with Stat-3 and the microprocessor complex containing the RNase III (DROSHA) and the RNA helicase (p68). These Nanog-associated signaling complexes (containing Stat-3 and/or DROSHA and p68) then bind to miR-21 promoter region, resulting in miR-21 production leading to upregulation of IAP protein expression, tumor cell survival, and chemoresistance. (B) HA-CD44 interaction promotes miRNA-302 expression and chemoresistance: HA binding to CD44 promotes an association between CD44v3 and OCT4/SOX2/Nanog. Subsequently,

OCT4/SOX2/Nanog complexes interact with the promoter region (containing OCT4-, SOX2-, and Nanog-binding sites) of the miR-302 cluster resulting in miR-302 cluster gene expression and mature miR-302 production. The resultant miR-302 then functions to induce IAP (CIAP-1, CIAP-2, and XIAP) expression, tumor cell growth, self-renewal, clone formation, tumor cell survival, and chemoresistance in tumor cells. (C) HA-CD44 interaction promotes miRNA-10b expression and tumor migration/invasion: HA binding to CD44 promotes c-Src phosphorylation (kinase activation), which, in turn, causes phosphorylation of Twist. Phosphorylated Twist then interacts with the E-box elements of mR-10b promoter, resulting in miR-10b gene expression, and mature miR-10b production. The binding of HA to CD44 also enhances DOT1L upregulation and DOT1L/H3K79 methylation-mediated epigenetic changes, resulting in methyl-H3K79 binding to miR-10b promoter, and miR-10b gene expression/production. The expressed miR-10b then promotes upregulation of RhoGTPase-mediated cytoskeleton activation leading to tumor cell migration and invasion. Red dot represents DOT1L/H3K79-mediated histone modifications (via epigenetic changes).

result in downregulation of survival proteins (e.g., cIAP-1, cIAP2, and XIAP) and upregulation of PDCD4 leading to tumor cell apoptosis/death and chemosensitivity in head and neck cancer (19, 65-67). Thus, this newly-discovered Nanog-Stat-3-regulated miR-21 signaling pathways during HA-CD44 interaction may be considered as another new drug target to treat cancers.

\section{The Expression of miR-21 and JNK/c-Jun Signaling}

Induction of oncogenic signaling frequently involves abnormal JNK-regulated c-Jun activities $(71,72)$. The transcription factor, c-Jun belongs to the AP-1 family which has been shown to play an important role in regulating cell transformation (73). Specifically, c-Jun has been shown to regulate the expression of p53 and cyclin D1 $(73,74)$ and has also been shown to accelerate leukemogenesis by activating cell cycle-related genes in cancer cells (73). JNK-regulated c-Jun often functions as a "bodyguard" which prevents certain gene modification(s) during cancer-related process (73-76). A previous study showed that c-Jun involves transcriptional activation of miR-21 at the miR21 promoter region located at AP-binding sites (76). HA-CD44 binding has also been shown to cause miR-21 production in a JNK/c-Jun-dependent manner in breast tumor cells (67) (Figure 3A). We have found that inhibition of JNK/c-Juninduced miR-21 signaling by various signaling perturbation agents such as JNK inhibitor or c-Jun siRNA or anti-miR-21 inhibitor effectively downregulates the expression of survival proteins such as $\mathrm{Bcl} 2$ and IAP family of proteins leading to apoptosis/cell death and chemosensitivity. These findings strongly suggest that JNK/c-Jun-regulated miR-21 activated by HA-CD44 interaction plays a pivotal role in tumorigenesis and 
drug resistance. Consequently, it is possible to design therapeutic drugs to target JNK/c-Jun-regulated miR-21 for the treatment of HA/CD44-mediated cancer.

\section{HA-CD44-Mediated miR-10b Signaling in the Regulation of Tumor Cell Migration and Invasion}

Tumor-specific phenotypes (e.g., tumor cell migration, invasion and metastasis) are often regulated by oncogenic signaling processed and/or cytoskeleton functions (1). Overexpression of miRNA-10b has been shown to be closely associated with upregulation of RhoC during glioma invasion and migration (77). In addition, the expression of a zinc finger protein, KLF4 (Kruppel-like factor 4) was found to be regulated by miR-10b in certain cancer cell lines (78). Moreover, it has been reported that miR-10b is responsible for activating both tumor cell invasion and metastasis (79). HA appears to interact with CD44 and induces miR-10b expression in head and neck cancer cells (32, 33). Interestingly, $200 \mathrm{kDa}-\mathrm{HA}$ fragments (to a lesser extent 5 $\mathrm{kDa}, 20 \mathrm{kDa}$, or $700 \mathrm{kDa}$ ) appears to preferentially enhances miR-10b expression in CSCs from head and neck cancer cells (32). The level of miR-10b expression is significantly higher (at least 5-10-fold increase) than other miRNAs (e.g., miR373, 27b,181-miRNA, miR-34b, and miR-145) detected in 200 $\mathrm{kDa}-\mathrm{HA}$-treated head and neck cancer cells (32). Here, several HA/CD44-mediated miR-10b signaling events and functions in various cancers will be described below:

\section{c-Src and Twist Signaling in the Regulation of miR-10b Expression}

Src kinase family members (e.g., Lck, Yes, and Fyn) have been shown to participate in CD44-mediated cellular signaling processes (80-82). For example, during T-cell activation Lck is found to be tightly linked to CD44 (80). Both Lck and Fyn have also been shown to be closely complexed with CD44 in a specialized plasma membrane domain enriched in glycosphingolipid in lymphoid cells (81). Moreover, CD44 has been shown to form a tight association with other Src kinase family of proteins (e.g., c-Src, Yes, and Fyn) during abnormal prostate cancer cell proliferation and growing processes (82). These findings strongly support the notion that CD44 and certain c-Src kinases family members are physically linked and functionally coupled.

Twist (one of c-Src substrates) has been shown to promote a variety of tumor cell-specific functions (e.g., EMT transition, invasion and drug resistance) (83-85). Twist is also considered as a putative oncogene for its role in regulating CD44expressing breast cancer stem cells (CSCs) (86). Several Twistregulated oncogenic events have been reported to be regulated by the binding of Twist to the promoters (containing the Eboxes) of specific genes (e.g., E-cadherin) required for tumor cell survival and invasiveness (87) as well as transcriptionally repression of E-cadherin gene expression in breast cancer (88). Previous studies showed that $\mathrm{c}$-Src-activated Twist promotes miR-10b expression in breast tumor cells $(79,89)$. During HA/CD44-mediated signaling process, Twist phosphorylated by c-Src is also able to interact with miR-10 promoter (with E-box domain) and activates the onset of miR-10b gene expression/production and tumor cell-specific activities in cancer cells (89). Treatment of cancer cells with c-Src inhibitor, PP2, or Twist siRNA significantly blocks the production of HA/CD44mediated miR-10 expression and downstream RhoGTPase (RhoC)-ROK effector functions (89). These observations strongly suggest that HA-CD44 interaction promotes miR-10b expression required for tumor cell-specific functions (e.g., cytoskeletonassociated metastasis, invasion, and metastasis) in a c-Src/Twistdependent manner.

\section{Role of Epigenetic Modifications in Regulating miR-10b Expression}

Epigenetic regulation via histone methylation participates in modifying chromatin organization together with reprogramming gene expression during cancer progression (90). The histone methyltransferase, DOT1 is known to be solely responsible for catalyzing methylation of histone at lysine 79 residues in three different ways such as H3K79me1/H3K79me2/ H3K79me3 in budding yeast, Saccharomyces cerevisiae (91, 92). Mammalian DOT1 (so-called DOT1L) has also been documented to display an ability to conduct histone methylation at lysine 79 residues as methyltransferases involved in modifications of gene expression (93). Both histone methyltransferases play an important role in H3K79 methylation involved in transcriptional regulation for the DNA damage checkpoint, meiotic checkpoint and cell cycle progression (94). Abnormal DOT1L-mediated H3K79 methylation has also been detected in mixed lineage leukemia (MLL) (95). In addition, suppression of DOT1L expression causes a reduction of tumor cell growth (96). These findings all indicate that histone methyltransferase (e.g., DOT1L) is closely involved in the development of cancer. DOT1L-mediated methylation of histone $\mathrm{H} 3$ at lysine 79 (H3K79) is also involved in the development of embryonic stem (ES) cells (97). Recent studies indicate that the activity of histone methyltransferase (e.g., DOT1L) can be detected in HA-activated head and neck cancer stem cells (CSCs) (89). Specifically, HA promotes DOT1Lregulated $\mathrm{H} 3 \mathrm{~K} 79$ methylation of miR-10b promoter binding sites leading to miR-10 production resulting in CSC-specific functions in head and neck cancer (Figure 3C). Silencing of DOT1L with DOT1LsiRNA and/or miR-10b with antagomirs (an antimiR-10 inhibitor) significantly decreases the amount of miR$10 \mathrm{~b}$ production resulting in downregulation of RhoC expression and tumor cell migration/invasion $(66,74)$. These findings may provide ground work for the development of new therapeutic drugs to target either DOT1L or miR-10 for the treatment of HA/CD44-activated cancer.

\section{Nanog/Oct4/Sox2 Signaling in Regulating miR-302 Expression and Cancer Stem Cell (CSC) Activation and Chemotherapy Resistance}

The miR-302 family which encodes a cluster of eight miRNAs has been shown to be important in the "stemness" properties of either normal and abnormal stem cells (98-100). These observations 
strongly suggest that there is a close involvement of miR-302 in the regulation of pluripotency of stem cells. The transcription factors such as Nanog, Oct4, and Sox 2 often interact with each other during transcriptional events $(61,100,101)$. Oct4, Sox2, and Nanog have also been detected to co-occupy the promoter sites of miR-302 for the activation of target genes required for development and oncogenesis $(61,100,101)$. In addition, miR-302 family plays key roles in regulating cell proliferation and cell fate determination during differentiation at the posttranslational level $(61,100,101)$. A previous study showed that HA binding to CD44 promotes the expression of miR-302 in a Nanog/Oct4/Sox2-dependent manner in head and neck cancer stem cells (CSCs) (31) (Figure 3B).

Several miR-302 downstream targets such as AOF1 and AOF2 known as lysine-specific histone demethylases have been shown to play a role in demethylating $\mathrm{H} 3 \mathrm{~K} 4$ and inhibiting transcription of genes $(31,102,103)$. Suppression of AOF1 and AOF2 is known to induce DNA (cytosine-5)-methyltransferase 1 (e.g., DNMT1) degradation and global demethylation leading to reprogramming of somatic cells into induced pluripotent stem cells (31). HACD44-activated miR-302 has also been shown to cause DNMT1 reduction and DNA demethylation in CD44v3-expressing cancer stem cells (CSCs) (31). Moreover, this DNA demethylation process regulated by HA-CD44-activated miR-302 can activate the expression of several Inhibitor of Apoptosis Protein (IAP) family of proteins such as c-IAP1, c-IAP2, and XIAP which appear to be closely linked to several important activities unique for cancer stem cells (CSCs) isolated from head and neck caner (31) (Figure 3B). Most importantly, treatments of CSCs with anti-miR-302 inhibitors readily upregulate lysine-specific histone demethylases and reduces DNA global demethylation as well as impairs HA/CD44-activated CSC functions (79). It is likely that miR-302 signaling pathway regulated by stem cell markers such as Nanog/Oct4/Sox2 during HA-CD44 interaction may be used as a novel therapeutic drug target to downregulate cancer stem cell (CSC) functions and to overcome chemotherapy resistance in cancer cells.

\section{HA-CD44 INTERACTION IN STIMULATING LNCRNA (UCA1) SIGNALING AND TUMOR PROGRESSION}

The evolutionarily conserved long non-coding RNAs (socalled lncRNAs $>200$ nucleotides) are now recognized as a major component of the human transcriptome (104, 105). Most of these molecules remain to be functionally unknown (104, 105). Dysregulation of lncRNAs frequently involves alterations of transcriptional and post-transcriptional activities of gene regulation in many cancers (106-111). For example, downregulation of PTCSC3 was detected in thyroid cancers (112). Malfunction of HULC and XIST is also reported in

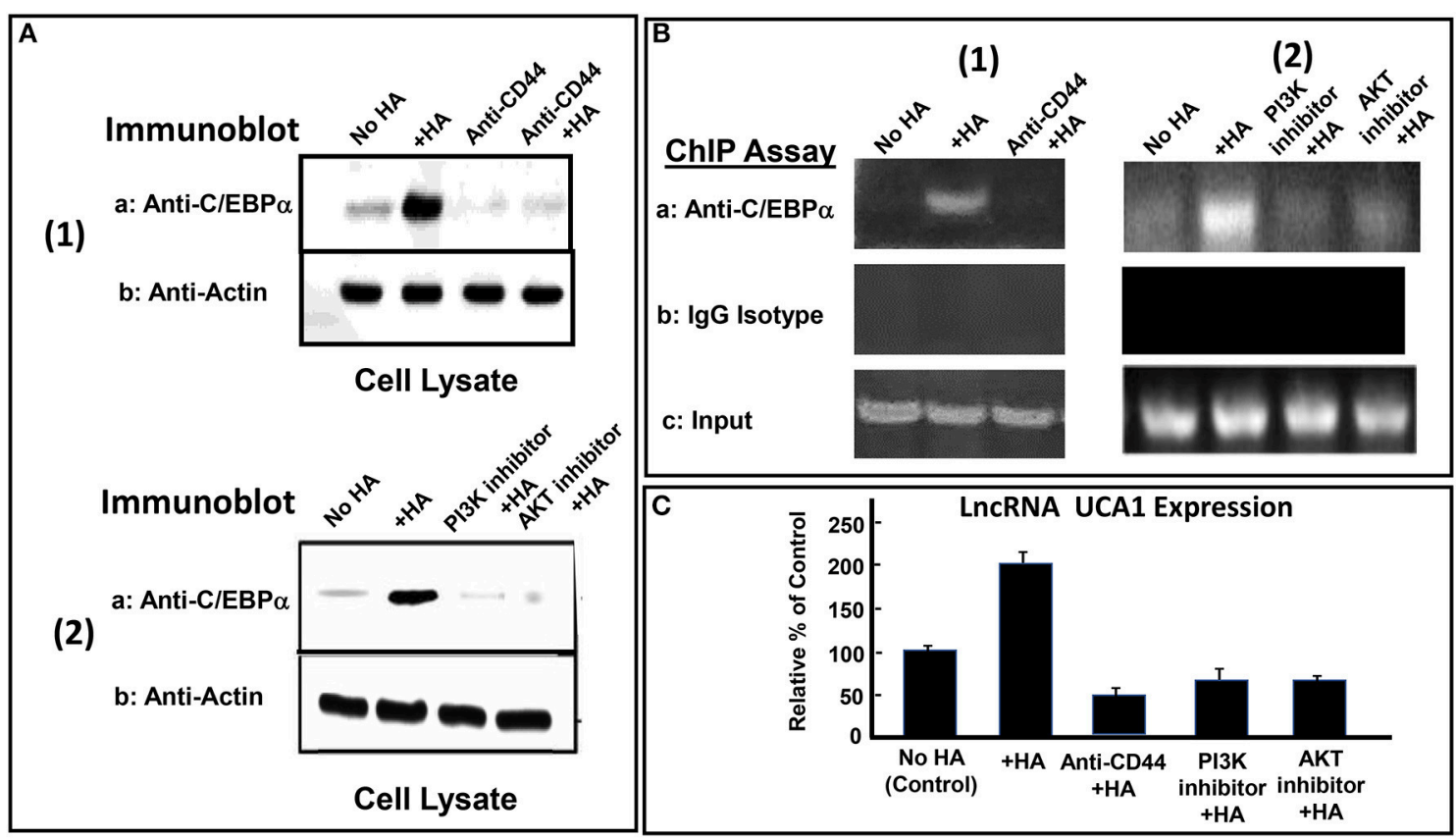

FIGURE 4 | HA-CD44-mediated LncRNA UCA1 expression in tumor cells. (A-1) Detection of C/EBP $\alpha$ phosphorylation in CD44v3high HSC-3 cells treated with no HA, (lane 1); or with HA (lane 2); or with anti-CD44 antibody with no HA (lane 3); or with anti-CD44 antibody + HA (lane 4). (A-2) Detection of C/EBPa phosphorylation in CD44v3high HSC-3 cells treated with no HA, (lane 1); or with HA (lane 2); or with PI3K inhibitor (GDC-0941) plus HA, (lane 3); or with AKT inhibitor (GSK795) plus HA (lane 4). (B) ChIP assay of p-C/EBP $\alpha$ binding to IncRNA UCA1 promoter in CD44v3high HSC-3 cells treated with no HA (lane 1) or with HA (lane 2) or with PI3K inhibitor (GDC-0941) plus HA (lane 3) or with AKT inhibitor (GSK795) plus HA (lane 4) using anti-p-C/EBP $\alpha$ or lgG control. Co-immunoprecipitated DNA was amplified by PCR with primers specific for the IncRNA UCA1 promoter. (C) The expression of IncRNA UCA1 by qRT-PCR in CD44v3high head and neck cancer cells (HSC-3 cells) treated with no HA (bar 1) or with HA (bar 2) or with anti-CD44 antibody plus HA (lane 3) or with PI3K inhibitor (GDC-0941) plus HA (bar 4) or with AKT inhibitor (GSK795) plus HA (bar 5) using IncRNA UCA1-specific primers and Q-PCR assay. 
various cancers (113-118). Furthermore, both GAPLINC and MALAT1 have been used as unfavorable predictors for a few solid tumor cancers (119-123). Overexpression of HOTAIR is linked to metastasis in colorectal, liver, pancreatic, breast and gastric cancers (124-131) whereas ANRIL and PRNCR1 upregulation is detected in prostate cancer $(132,133)$. High levels of KCNQ1OT1 and H19 expression were also detected in colorectal cancer (132) and hepatocellular carcinoma (133), respectively. Therefore, aberrant expression of certain lncRNAs appears to be closely linked to various tumor progression.

Another important member of lncRNA family, urothelial carcinoma associated 1 (IncRNA UCA1) has been shown to be correlated with tumor growth, progression and recurrence (108-111). Several studies focusing on the transcriptional regulation of lncRNA UCA1 show that many transcription factors (e.g., C/EBP $\alpha$, Ets-2, TAZ/YAP/TEAD, HIF-1 $\alpha$, SATB1, CAPER $\alpha / T B X 3$, etc.) may participate in the regulation of IncRNA UCA1 by binding to the promoter sites of lncRNA UCA1 (134-139). A specific example for the regulation of lncRNA UCA1 expression by certain transcription factor during HACD44 interaction in head and neck cancer cells is described as follows:

\section{Role of C/EBP $\alpha$ in Regulating HA-CD44-mediated IncRNA UCA1 Expression}

Many transcription factors have been shown to be involved in the regulation of lncRNA UCA1 expression (135). For example, the interaction between the transcription factor, $\mathrm{C} / \mathrm{EBP} \alpha$ and the promoter of IncRNA UCA1 often promotes an upregulation of lncRNA UCA1 production leading to anti-cell death and cell survival (135). Recent study indicates that a cross-talk between PI3K-AKT pathway and IncRNA UCA1 expression also occurs during breast cancer cell invasion (140). We have found that $\mathrm{HA}$ induces $\mathrm{C} / \mathrm{EBP} \alpha$ phosphorylation in $\mathrm{CD} 44 \mathrm{v} 3$ high head and neck cancer cells (HSC-3 cells) in a CD44-dependent

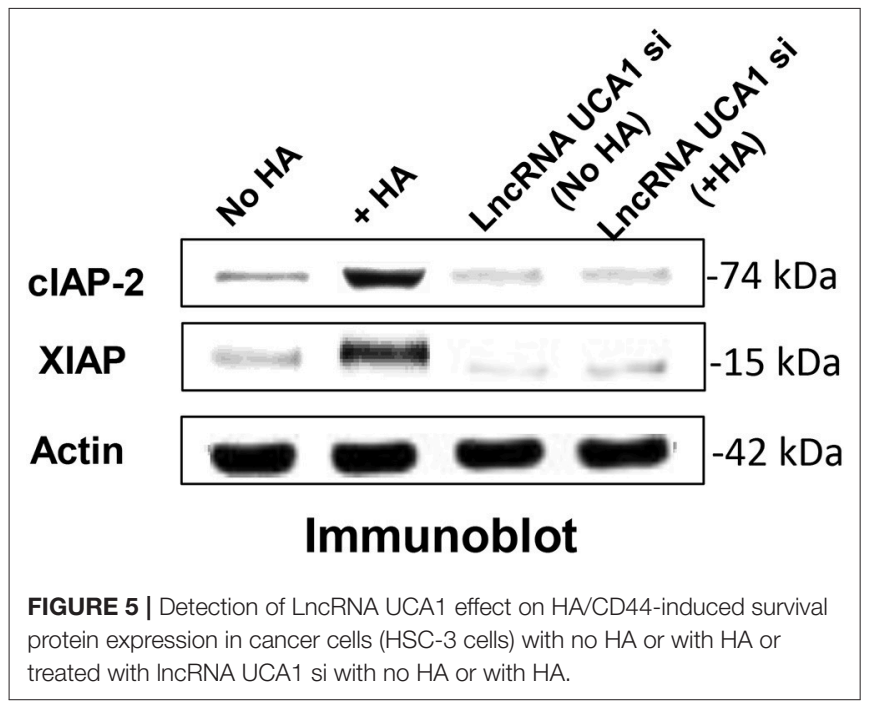

manner (Figure 4A-1). Downregulation of AKT by treating CD44v3high HSC-3 cells with AKT inhibitor (GSK795) or PI3K inhibitor (GDC-0941) blocks HA-mediated C/EBP $\alpha$ phosphorylation (Figure 4A-2). These findings suggest that $\mathrm{C} / \mathrm{EBP} \alpha$ phosphorylation is $\mathrm{PI} 3 \mathrm{~K}-\mathrm{AKT}$ signaling-dependent in HA-treated CD44v3high head and neck cancer cells (HSC-3 cells) (Figures 4A-1, 2). To examine whether phosphorylated $\mathrm{C} / \mathrm{EBP} \alpha$ (induced by HA-mediated CD44v3-mediated PI3KAKT activation) directly interacts with the promoter region of lncRNA UCA1, chromatin immunoprecipitation (ChIP) assays were performed in head and neck cancer cells with HA (or without HA). Preliminary data indicate that phosphorylated $\mathrm{C} / \mathrm{EBPa}$ is directly recruited into the promoter region of lncRNA UCA1 in HA-treated CD44v3high head and neck cancer cells, resulting in lncRNA UCA1 expression (Figure 4B-1). However, HA-mediated recruitment of phosphorylated C/EBPa into LncRNA UCA1 promoter sites appears to be blocked in cells treated with anti-CD44 antibody (Figure 4B-1). Consequently, lncRNA UCA1 expression is also inhibited (Figure 4C). Downregulation of $\mathrm{PI} 3 \mathrm{~K}$ or $\mathrm{AKT}$ by treating cells with either PI3K inhibitor (GDC-0941) or AKT inhibitor (GSK795) effectively inhibits the complex formation between phospho-C/EBPa and the promoter region of lncRNA UCA1 in HA-treated CD44v3high head and neck cancer cells, as well as lncRNA UCA1 production (Figure 4B-2 and Figure 4C). These findings suggest that the binding of phosphorylated $\mathrm{C} / \mathrm{EBPa}$ to the lncRNA UCA1 promoter and lncRNA UCA1 expression is CD44/PI3/AKT-dependent and GDC-0941/GSK795-sensitive in HA-treated CD44v3high head and neck cancer cells. Therefore, we believe that the regulation of IncRNA UCA1 expression in head and neck cancer cells is HA-dependent and CD44-specific.

\section{Role of IncRNA UCA1 in Regulating Tumor Cell Survival and Chemoresistance}

Several regulatory small and long non-coding RNAs have been well-documented in many cancers resistant to therapeutic drug (e.g., cisplatin) treatment (141-144). The ability of cisplatin to induce tumor cell death is often counteracted by the presence of anti-apoptotic regulators and/or survival proteins leading to chemoresistance (142-144). The IAP family (e.g., cIAP-2 and XIAP) is well-documented to play critical roles in promoting tumorigenesis through the action of both anti-apoptosis and anti-cell death (145). These proteins also

TABLE 1 | Chemosensitivity assay treatment.

\begin{tabular}{lc}
\hline Chemosensitivity assay treatment & Growth inhibition IC50 $(\boldsymbol{\mu} \mathbf{M})$ \\
\hline No HA (Control) & $1.00 \pm 0.05$ \\
+HA & $2.69 \pm 0.11$ \\
LncRNA UCA1si-treated cells (+HA) & $0.50 \pm 0.07$ \\
CIAP-2 siRNA-treated cells (+HA) & $0.42 \pm 0.04$ \\
XIAP siRNA-treated cells (+HA) & $0.45 \pm 0.02$
\end{tabular}

*The procedures for measuring cisplatin-induced tumor cell growth inhibition (IC 50) is the same as described previously (31-33). 


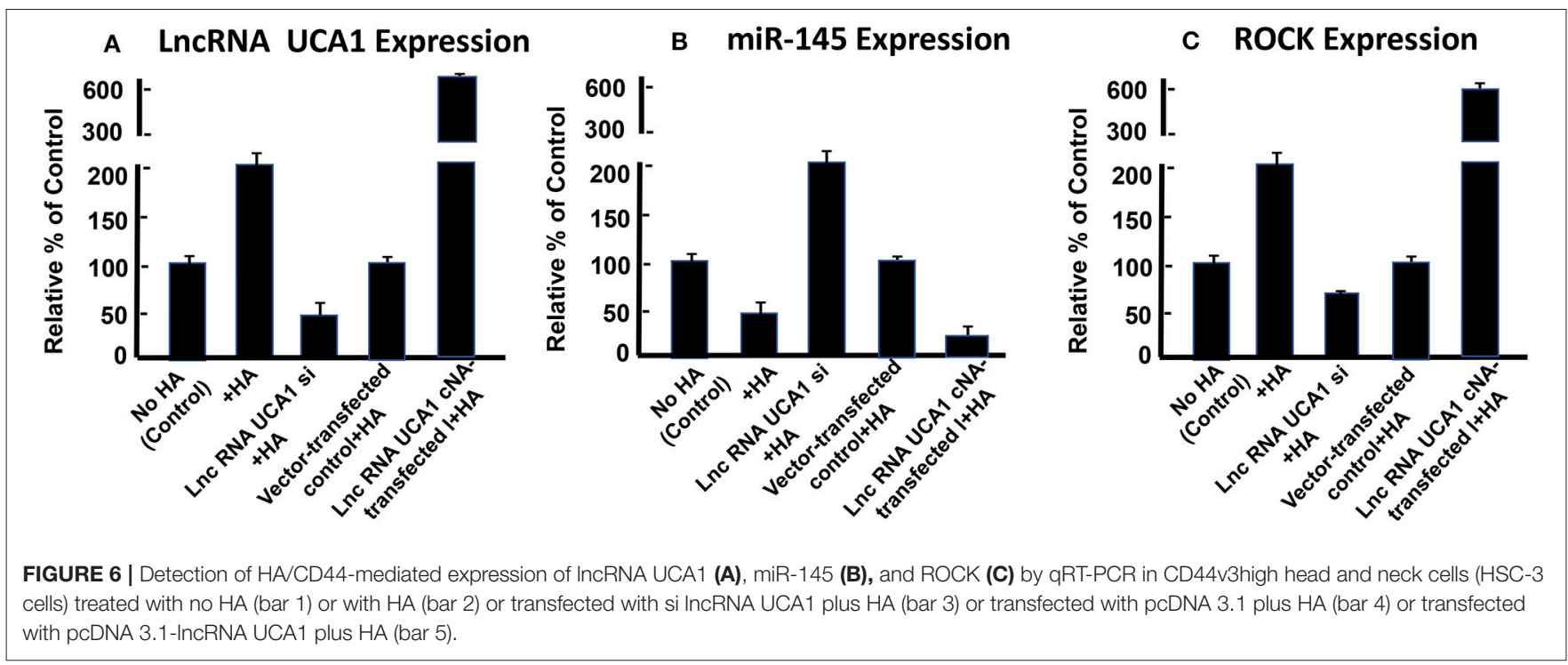

participate in chemoresistance by reducing tumor cell death or apoptosis caused by chemotherapeutic drugs (146). Although several other survival proteins such as $\mathrm{Bcl} 2$ and $\mathrm{BclxL}$ are known to play roles in regulating tumor cell survival and chemoresistance in cancer cells during HA-CD44 binding (147), the involvement of cIAP-1, cIAP-2, and XIAP in promoting $\mathrm{HA} / \mathrm{CD} 44$-mediated tumor cell survival and drug resistance has only recently received some attentions.

LncRNA UCA1 has been reported to induce drug resistance in bladder cancer and many other cancers $(108,109,148-$ $163)$, thereby greatly reducing the efficacy of cancer therapy. Recently, we found that the expression of both cIAP-2 and XIAP appear to be downregulated in head and neck cancer cells treated with anti-lncRNA UCA1 inhibitor (Figure 5). The suppression of these survival proteins leads to tumor cell death and effective chemotherapeutic drug treatment (Table 1). The fact that reduction of anti-apoptosis proteins (cIAP-2 or XIAP) by treating head and neck cancer cells with specific inhibitory siRNAs (e.g., cIAP-2 siRNA or XIAP siRNA) during HA/CD44 interaction appears to increase chemosensitivity suggests that downregulation of lncRNA UCA1 together with blockage of survival protein pathways may provide a new therapeutic strategy in cancer therapy, especially dealing with drug resistance.

\section{The Role of IncRNA UCA1 in Regulating miR-145-ROCK1 Pathway and Tumor Cell Migration and Invasion}

During the regulation of miRNA expression, lncRNA can compete the common response elements of miRNAs (161). LncRNAs can also bind DNAs, RNAs and proteins by acting as decoy, guide or scaffold (161). LncRNA has been reported to bind to many different miRNAs including miR-145 in a variety of cancer cells resulting in carcinogenesis, tumor cell migration, invasion or drug resistance (152, 153, 162-167,
167-169). Recent observations indicate that lncRNA UCA1 promotes migration and invasion in bladder cancer cells (164). Accumulating evidence indicates that miR-145 known as a tumor suppressor is frequently downregulated in various cancers (170). It has been postulated that a signaling pathway may be involved in the formation of a regulatory loop between lncRNA UCA1 and miR-145 via a reciprocal repression process required for tumor cell-specific activities (e.g., migration and/or invasion) (164). There is evidence that upregulation of miR-145 impairs cancer cell motility by downregulating the expression of its target genes including ROCK (a Rho-associated protein kinase), a key regulator of actin cytoskeleton reorganization required for cancer cell migration and invasion $(164,171)$. Thus, both up- or down-regulation of miR-145 appear to play important roles in cancer cell-related activities (e.g., cell migration and invasion).

Furthermore, it has been reported that lncRNA UCA1 suppresses the tumor suppressor miR-145 for tumor cell invasion/migration through the expression of miR-145 target proteins such as ROCK1 in glioma cancer cells (109). These findings are consistent with our observations showing that HACD44v3 interaction stimulates lncRNA UCA1 expression in CD44v3high tumor cells (Figure 6A). Moreover, upregulation of lncRNA UCA1 (by transfecting cells with lncRNA UCA1 cDNA, but not vector control cDNA) significantly suppresses miR-145 expression (Figure 6B) leading to an increase of miR145 target gene, ROCK1 expression (Figure 6C). Conversely, when CD44v3high head and neck cancer cells (HSC-3 cells) were transfected with lncRNA UCA RNAi inhibitor, the expression level of miR-145 is significantly up-regulated (Figure 6B). Consequently, ROCK1 (a miR-145 target) gene/protein is downregulated (Figure 6C). These findings suggest that the miR145-ROCK1 pathway serves as a possible downstream functional target for lncRNA UCA1 in CD44v3high head and neck cancer cells. Furthermore, our recent data show that upregulation of lncRNA UCA1 by HA-CD44v3 binding in CD44v3high head 
TABLE 2 | Cell migration and invasion treatments.

\begin{tabular}{lcc}
\hline $\begin{array}{l}\text { Cell migration and invasion } \\
\text { treatments }\end{array}$ & $\begin{array}{c}\text { Tumor cell migration } \\
\text { (\% of control) }\end{array}$ & $\begin{array}{c}\text { Tumor cell invasion } \\
\text { (\% of control) }\end{array}$ \\
\hline No HA (Control) & $100 \pm 2$ & $100 \pm 5$ \\
+HA & $223 \pm 12$ & $245 \pm 10$ \\
LncRNA UCA1 si-treated (+HA) & $65 \pm 3$ & $63 \pm 2$ \\
miR-145 mimic-treated cells (+HA) & $65 \pm 2$ & $62 \pm 2$ \\
ROCK inhibitor (Y-27632)-treated & $60 \pm 2$ & $66 \pm 3$ \\
cells (+HA) & & \\
\hline
\end{tabular}

The measurements of in vitro tumor cell migration and invasion were performed using twenty-four transwell units as described previously $(66,131,154)$.

and neck cancer cells significantly enhances ROCK-mediated head and neck cancer cell migration and invasion (Table 2). Treatment of cells with lncRNA UCA1 RNAi inhibitor or miR-145 mimic or a ROCK inhibitor, Y-27632 significantly reduces tumor cell invasion (Table 2). These observations suggest that the miR-145-ROCK1 pathway serves as a new downstream functional target for lncRNA UCA1 in regulating CD44v3high head and neck cancer cell activities including cell migration and invasion. The results of these studies strongly indicate that lncRNA LncRNA UCA1 is one of the important regulatory molecules in controlling miR-145-ROCK pathway and tumor cell migration and invasion.

In summary, we would like to propose that HA binding CD44 stimulates $\mathrm{PI} 3 \mathrm{~K}$ and $\mathrm{AKT}$ signaling which in turn causes $\mathrm{c} / \mathrm{EBP} \alpha$ phosphorylation. Phosphorylated $\mathrm{c} / \mathrm{EBP} \alpha$ then binds to the site of LncRNA UCA1 promoter and induces transcription activity for the expression of LncRNA UCA1 which then upregulates survival proteins (IAPs) and chemoresistance. HA/CD44-activated IncRNA UCA1 also downregulates miR145 expression and stimulates ROCK expression required for cytoskeletal activation and tumor cell motility (e.g., migration and invasion) (Figure 7). Therefore, it is feasible to use either LncRNA UCA1 si treatment and/or ROCK inhibitor to limit tumor cell migration and invasion (Table 2) and to reduce HA/CD44-induced tumor metastasis and progression.

\section{CONCLUSION}

The newly discovered signaling events regulated by HA-CD44 interaction may be very useful for a better understanding of cancer cell-specific behaviors including transcriptional activation, tumor cell growth, inflammatory cytokine/chemokine production, migration/invasion and survival as well as chemoresistance as summarized in Figure 8. Consequently, targeting CD44 using anti-CD44 and/or CD44 variant-specific antibody and/or anti-sense strategies to downregulate CD44 and/or CD44 variants may be a possible choice for the development of new cancer cell-based therapies. Furthermore, HA-based nanoparticles containing therapeutic drugs (e.g., cisplatin or doxorubicin) may be used to accurately deliver therapeutic drugs into $\mathrm{CD} 44 \mathrm{v}$ isoform-expressing cancer cells to enhance chemo-sensitivity and downregulate CD44v

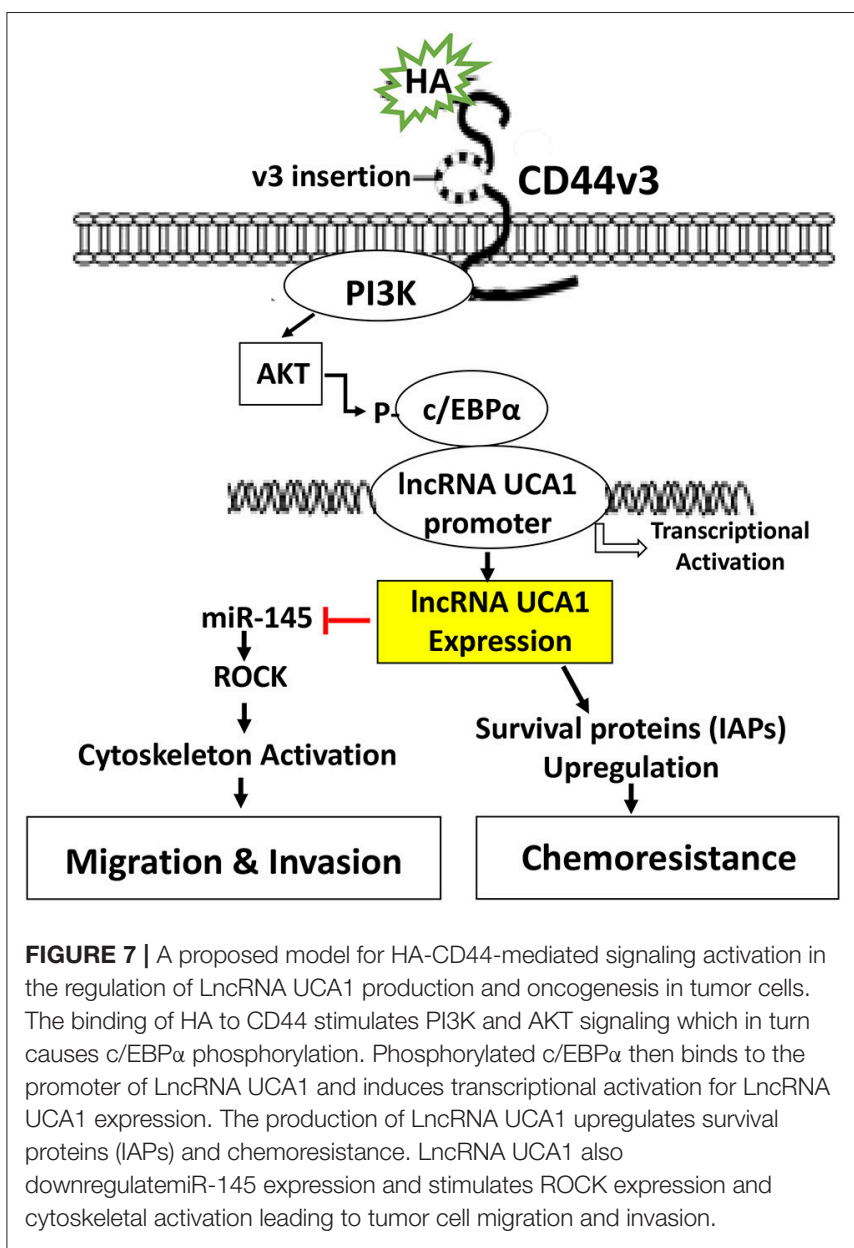

isoform-mediated oncogenic signaling. It is also feasible to design signaling perturbation strategies to downregulate the expression of HA/CD44-regulated Nanog/Oct4/Sox2 and cJun as well as certain miRNAs (e.g., miR-21, miR-10b, and miR-302) using specific inhibitors such as siRNA and shRNA and anti-miRNA inhibitor approaches to simultaneously suppress both oncogenic behaviors and cancer progression. Since many LncRNAs have been shown to be closely associated with tumor cell-specific properties including cell survival, chemoresistance, tumor cell migration and invasion, it will also be possible to develop novel signaling perturbation techniques to simultaneously inhibit both oncogenic miRNAs and LncRNA UCA1 using miRNA-21/miRNA-10b/miR302 RNAi inhibitor and/or lncRNA UCA1 RNAi inhibitor treatments. These strategies could synergistically cause apoptotic responses and chemosensitivity. These new approaches could indicate that the impairment of specific signaling pathways together with suppression of miRNAs (miR-21/miR-10b/miR-302) and/or lncRNA UCA1 in HACD44-activated cancer cells may be more effective than chemotherapy alone. Novel therapeutic strategies described in this review may offer helpful information for understanding the initiation and development mechanisms of different cancers 


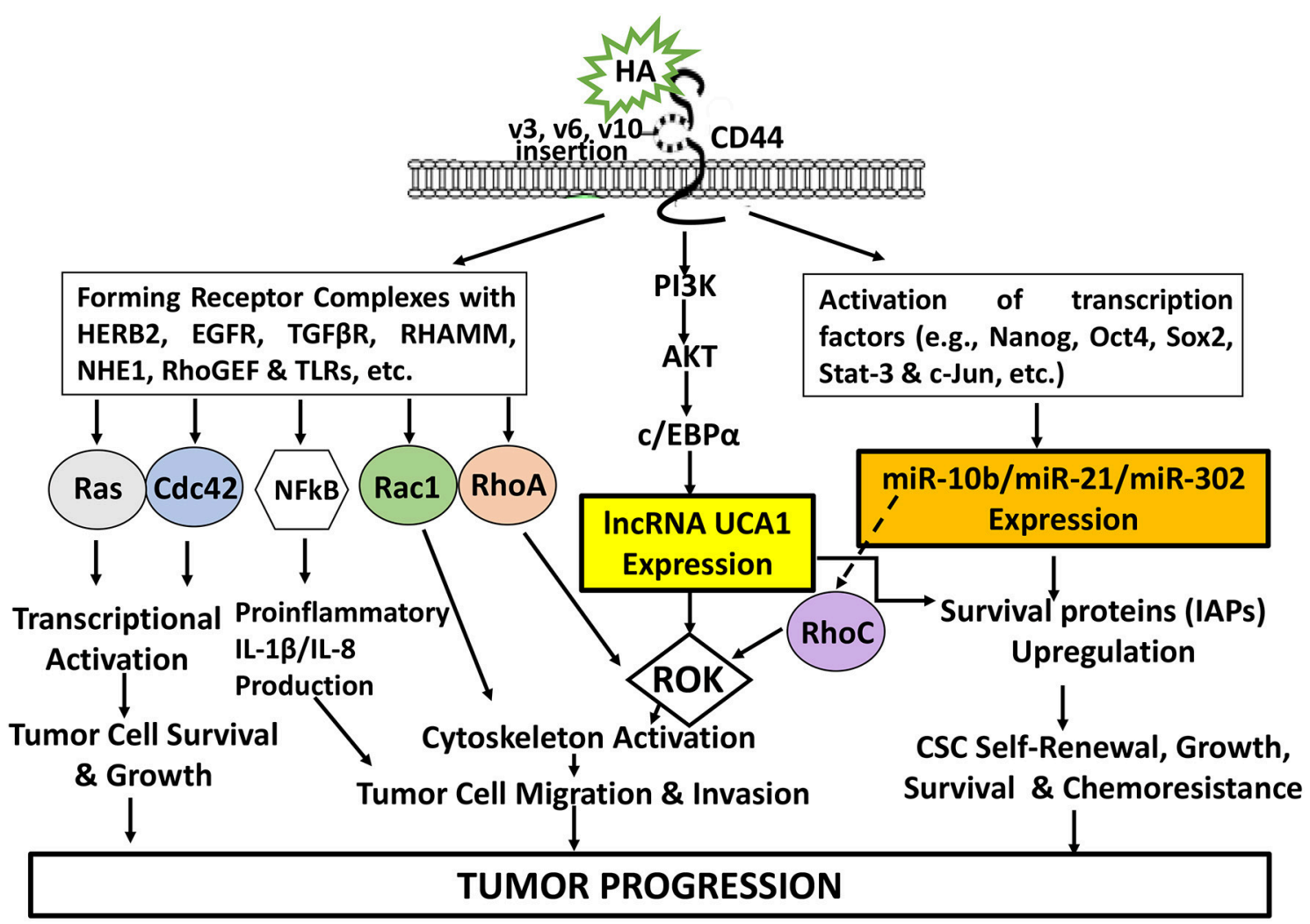

FIGURE 8 | An Illustration of HA-CD44 interaction-induced oncogenic signaling events in cancer. The binding of HA (large vs. small HA) to CD44v isoforms interaction stimulates CD44-other receptor (HERB2, EGFR, TGF $\beta$ R, RHAMM, NHE1, RhoGEF, and TLRs, etc.) complex formation and Ras/Cdc42/Rac1/RhoA/NFkB activation for transcriptional activation and proinflammatory cytokine/chemokine production as well as tumor cell survival, growth, invasion and migration. HA-CD44 interaction also promotes PI3K/AKT activation and LncRNA (UCA1) production resulting in ROK-mediated cytoskeleton function required for tumor cell migration and invasion. Moreover, HA/CD44 activates transcriptional factor-induced miRNA (miR-10b/miRNA-21/miR-302) expression leading to CSC self-renewal, growth, survival and chemoresistance. Furthermore, the induction of miR-21 by HA-CD44 interaction also stimulates RhoC upregulation and ROK-regulated tumor cell migration and invasion. All these events contribute to HA-CD44 interaction-mediated tumor progression.

comprehensively and suggest new therapeutic targets for clinical treatment of HA/CD44-activated cancer development and tumor progression.

\section{AUTHOR CONTRIBUTIONS}

The author confirms being the sole contributor of this work and has approved it for publication.

\section{REFERENCES}

1. Jiang WG, Puntis MCA, Hallett MB. Molecular and cellular basis of cancer invasion and metastasis: implications for treatment. $\mathrm{Br} \quad \mathrm{J}$ Surg. (1994) 81:1576-90. doi: 10.1002/bjs.18008 11107

2. Lauffenburger DA, Horwitz AF. Cell migration: a physically integrated molecular process. Cell. (1996) 84:359-69. doi: 10.1016/S0092-8674(00)81280-5

3. Kesslern $\mathrm{T}$, Hache $\mathrm{H}$, Wierling $\mathrm{C}$. Integrative analysis of cancer-related signaling pathways. Front. Physiol. (2013) 4:124. doi: 10.3389/fphys.2013.00124

\section{ACKNOWLEDGMENTS}

We would like to thank both Dr. Gerard J. Bourguignon and Ms. Christine Earle for their assistance with manuscript preparation and LncRNA UCA1 studies. LB is a VA Senior Research Career Scientist. This work was sponsored by United States Public Health Grants (R01 CA66163) and by Veterans Affairs Merit Review Awards. 
8. Weigel PH, Hascall VC, Tammi M. Hyaluronan synthases. J Biol Chem. (1997) 272:13997-4000. doi: 10.1074/jbc.272.22.13997

9. Itano N, Kimata K. Expression cloning and molecular characterization of HAS protein, a eukaryotic hyaluronan synthase. J Biol Chem. (1996) 271:9875-8. doi: 10.1074/jbc.271.17.9875

10. Bourguignon LY, Gilad E, Peyrollier K. Heregulin-mediated ErbB2-ERK signaling activates hyaluronan synthases leading to CD44-dependent ovarian tumor cell growth and migration*. J Biol Chem. (2007) 282:19426-41. doi: 10.1074/jbc.M610054200

11. Stern R, Jedrzejas MJ. Hyaluronidases: their genomics, structures, and mechanisms of action. Chem Rev. (2006) 106:818-39. doi: $10.1021 / \mathrm{cr} 050247 \mathrm{k}$

12. Underhill C. CD44: the hyaluronan receptor. J Cell Sci. (1992) 103:293-8.

13. Bourguignon LY. CD44-mediated oncogenic signaling and cytoskeleton activation during mammary tumor progression. J Mammary Gland Biol Neoplasia. (2001) 6:287-97. 16 doi: 10.1023/A:1011371523994

14. Bourguignon LY. Hyaluronan-mediated CD44 activation of RhoGTPase signaling and cytoskeleton function promotes tumor progression. Semin Cancer Biol. (2008) 18:251-9. doi: 10.1016/j.semcancer.2008. 03.007

15. Bourguignon LY, Shiina M, Li JJ. Hyaluronan-CD44 interaction promotes oncogenic signaling, microRNA functions, chemoresistance, and radiation resistance in cancer stem cells leading to tumor progression. Adv Cancer Res. (2014) 123:255-75. doi: 10.1016/B978-0-12-800092-2.00010-1

16. Screaton GR, Bell MV, Jackson DG, Cornelis FB, Gerth U, Bell JI. Genomic structure of DNA coding the lymphocyte homing receptor CD44 reveals 12 alternatively spliced exons. Proc Natl Acad Sci USA. (1992) 89:12160-4. doi: 10.1073/pnas.89.24.12160

17. Screaton GR, Bell MV, Bell JI, Jackson DG. The identification of a new alternative exon with highly restricted tissue expression in transcripts encoding the mouse Pgp-1 (CD44) homing receptor. Comparison of all 10 variable exons between mouse, human and rat. $J$ Biol Chem. (1993) 268:12235-8.

18. Iida N, Bourguignon LY. Coexpression of CD44 variant (v10/ex14) and CD44S in human mammary epithelial cells promotes tumorigenesis. J Cell Physiol. (1997) 171:152-60. doi: 10.1002/(SICI)10974652(199705) 171:2<152::AID-JCP5>3.0.CO;2-N

19. Bourguignon LY. Matrix hyaluronan promotes specific microRNA upregulation leading to drug resistance and tumor progression. Int $J$ Mol Sci. (2016) 17:517. doi: 10.3390/ijms17040517

20. Lokeshwar VB, Iida N, Bourguignon LY. The cell adhesion molecule, GP116, is a new CD44 variant (ex14/v10) involved in hyaluronic acid binding and endothelial cell proliferation. J Biol Chem. (1996) 271:23853-64. doi: $10.1074 / j b c .271 .39 .23853$

21. Bourguignon LY, Bikle D. Selective hyaluronan-CD44 signaling promotes miRNA-21 expression and interacts with vitamin D function during cutaneous squamous cell carcinomas progression following UV irradiation. Front Immunol. (2015) 6:224. doi: 10.3389/fimmu.2015.00224

22. Bourguignon LY, Gunja-Smith Z, Iida N, Zhu HB, Young LJ, Muller WJ, et al. $\mathrm{CD} 44 \mathrm{v}(3,8-10)$ is involved in cytoskeleton-mediated tumor cell migration and matrix metalloproteinase (MMP-9) association in metastatic breast cancer cells. J Cell Physiol. (1998) 176:206-15. doi: 10.1002/(SICI)10974652(199807)176:1<206::AID-JCP22>3.0.CO;2-3

23. Kalish ED, Iida N, Moffat FL, Bourguignon LY. A new CD44V3containing isoform is involved in tumor cell growth and migration during human breast carcinoma progression. Front Biosci. (1999) 4:A1-8. doi: 10. 2741/A399

24. Franzmann EJ, Weed DT, Civantos FJ, Goodwin WJ, Bourguignon LY. A novel CD44v3 isoform is involved in head and neck squamous cell carcinoma progression. Otolaryngol Head Neck Surg. (2001) 124:426-32. doi: $10.1067 / \mathrm{mhn} .2001 .114674$

25. Wang SJ, Wreesmann VB, Bourguignon LY. Association of CD44v3containing isoforms with tumor cell growth, migration, matrix metalloproteinase expression, and lymph node metastasis in head and neck cancer. Head Neck. (2007) 29:550-8. doi: 10.1002/hed.20544

26. Wang SJ., Wong G, de Heer AM, Xia W, Bourguignon LY. CD44 variant isoforms in head and neck squamous cell carcinoma progression. Laryngoscope. (2009) 119:1518-30. doi: 10.1002/lary.20506
27. Wang SJ, Bourguignon LY. Role of hyaluronan-mediated CD44 signaling in head and neck squamous cell carcinoma progression and chemoresistance. Am J Pathol. (2011) 178:956-63. doi: 10.1016/j.ajpath.2010.11.077

28. Mack B, Gires O. CD44s and CD44v6 expression in head and neck epithelia. PLoS ONE. (2008) 3:e3360. doi: 10.1371/journal.pone.0003360

29. Prince ME, Sivanandan R, Kaczorowski A, Wolf GT, Kaplan MJ, Dalerba $\mathrm{P}$, et al. Identification of a subpopulation of cells with cancer stem cell properties in head and neck squamous cell carcinoma. Proc Natl Acad Sci USA. (2007) 104:973-8. doi: 10.1073/pnas.0610117104

30. Chikamatsu K, Ishii H, Takahashi G, Okamoto A, Moriyama M, Sakakura $\mathrm{K}$, et al. Resistance to apoptosis-inducing stimuli in $\mathrm{CD} 44+$ head and neck squamous cell carcinoma cells. Head Neck. (2012) 34:336-43. doi: 10.1002/hed.21732

31. Bourguignon LY, Wong G, Earle C, Chen L. Hyaluronan-CD44v3 interaction with OCT4-SOX2-Nanog promotes miR-302 expression leading to selfrenewal, clonal formation, and cisplatin resistance in cancer stem cells from head and neck squamous cell carcinoma. J Biol Chem. (2012) 287:32800-24. doi: 10.1074/jbc.M111.308528

32. Shiina M, Bourguignon LY. Selective activation of cancer stem cells by size-specific hyaluronan in head and neck cancer. Int J Cell Biol. (2015) 2015:989070. doi: 10.1155/2015/989070

33. Bourguignon LY, Wong G, Shiina M. Up-regulation of histone methyltransferase, DOT1L, by matrix hyaluronan promotes microRNA-10 expression leading to tumor cell invasion and chemoresistance in cancer stem cells from head and neck squamous cell carcinoma. J Biol Chem. (2016) 291:10571-85. doi: 10.1074/jbc.M115.700021

34. Toole BP, Hascall VC. Hyaluronan and tumor growth. Am J Pathol. (2002) 161:745-7. doi: 10.1016/S0002-9440(10)64232-0

35. Bourguignon LY. Hyaluronan-mediated CD44 signaling activates cancer stem cells in head and neck cancer. In: Burtness, Barbara, Golemis, Erica A, Editors. Molecular Determinants of Head and Neck Cancer, Basel: Springer Nature Switzerland AG (2018). doi: 10.1007/978-3-319-78762-6_19

36. Bourguignon LY, Singleton PA, Zhu H, Diedrich F. Hyaluronan-mediated CD44 interaction with RhoGEF and Rho kinase promotes Grb2-associated binder-1 phosphorylation and phosphatidylinositol 3-kinase signaling leading to cytokine (macrophage-colony stimulating factor) production and breast tumor progression. J Biol Chem. (2003) 278:29420-34. doi: 10.1074/jbc.M301885200

37. Toulany M, Rodemann HP. Phosphatidylinositol 3-kinase/Akt signaling as a key mediator of tumor cell responsiveness to radiation. Semin Cancer Biol. (2015) 35:180-90. doi: 10.1016/j.semcancer.2015.07.003

38. Chanmee $T$, Ontong $P$, Izumikawa $T$, Higashide $M$, Mochizuki $N$, Chokchaitaweesuk C, et al. Hyaluronan production regulates metabolic and cancer stem-like properties of breast cancer cells via hexosamine biosynthetic pathway-coupled HIF-1 signaling. I Biol Chem. (2016) 291:24105-20. doi: 10.1074/jbc.M116.751263

39. Bourguignon LY, Peyrollier K, Xia W, Gilad E. Hyaluronan-CD44 interaction activates stem cell marker Nanog, Stat-3-mediated MDR1 gene expression, and ankyrin-regulated multidrug efflux in breast and ovarian tumor cells. $J$ Biol Chem. (2008) 283:17635-51. doi: 10.1074/jbc.M800109200

40. Ricciardelli C, Ween MP, Lokman NA, Tan IA, Pyragius CE, Oehler MK. Chemotherapy-induced hyaluronan production: a novel chemoresistance mechanism in ovarian cancer. BMC Cancer. (2013) 13:476. doi: 10.1186/1471-2407-13-476

41. Bourguignon LY. Hyaluronan-CD44 interaction promotes microRNA signaling and RhoGTPase activation leading to tumor progression. Small GTPases. (2012) 3:53-9. doi: 10.4161/sgtp.19110

42. Singleton PA, Bourguignon LY. CD44v10 interaction with Rho-kinase (ROK) activates inositol 1,4,5-triphosphate (IP3) receptor-mediated Ca2+ signaling during hyaluronan (HA)-induced endothelial cell migration. Cell Motil Cytoskeleton. (2002) 53:293-316. doi: 10.1002/cm.10078

43. Singleton PA, Bourguignon LY. CD44 interaction with ankyrin and IP3 receptor in lipid rafts promotes hyaluronan-mediated $\mathrm{Ca} 2+$ signaling leading to nitric oxide production and endothelial cell adhesion and proliferation. Exp Cell Res. (2004) 295:102-18. doi: 10.1016/j.yexcr.2003.12.025

44. Matou-Nasri S, Gaffney J, Kumar S, Slevin M. Oligosaccharides of hyaluronan induce angiogenesis through distinct CD44 and 
RHAMM-mediated signalling pathways involving $\mathrm{Cdc2}$ and $\gamma$ adducin). Int $J$ Oncol. (2009) 35:761-73. doi: 10.3892/ijo_000 00389

45. Bourguignon LY, Singleton PA, Diedrich F, Stern R, Gilad E. CD44 interaction with $\mathrm{Na}+\mathrm{-H}+$ exchanger (NHE1) creates acidic microenvironments leading to hyaluronidase-2 and cathepsin B activation and breast tumor cell invasion. J Biol Chem. (2004) 279:26991-7007. doi: $10.1074 /$ jbc.M311838200

46. Bourguignon LY, Zhu H, Zhou B, Diedrich F, Singleton PA, Hung MC. Hyaluronan promotes CD44v3-Vav2 interaction with Grb2-p185(HER2) and induces Racl and Ras signaling during ovarian tumor cell migration and growth. J Biol Chem. (2001) 276:48679-92. doi: 10.1074/jbc.M106759200

47. Bourguignon LY, Gilad E, Brightman A, Diedrich F, Singleton P. Hyaluronan-CD44 interaction with leukemia-associated RhoGEF and epidermal growth factor receptor promotes Rho/Ras co-activation, phospholipase $\mathrm{C}$ epsilon-Ca2+ signaling, and cytoskeleton modification in head and neck squamous cell carcinoma cells. J Biol Chem. (2016) 281:14026-40. doi: 10.1074/jbc.M507734200

48. Bourguignon LY, Singleton PA, Zhu H, Zhou B. Hyaluronan promotes signaling interaction between $\mathrm{CD} 44$ and the transforming growth factor beta receptor I in metastatic breast tumor cells. J Biol Chem. (2002) 277:39703-12. doi: 10.1074/jbc.M204320200

49. Misra S, Hascll V, Markwald RR, Ghatak S. Interactions between hyaluronan and its receptors (CD44, RHAMM) regulate the activities of inflammation and cancer. Front. Immunol. 6:201. doi: 10.3389/fimmu.2015.00201

50. Entwistle J, Zhang S, Yang B, Wong C, Li Q, Hall CL, et al. Characterization of the murine gene encoding the hyaluronan receptor RHAMM. Gene. (1995) 163:233-8. doi: 10.1016/0378-1119(95)00398-P

51. Turley EA, Noble PW, Bourguignon LY. Signaling properties of hyaluronan receptors. J Biol Chem. (2002) 277:4589-92. doi: 10.1074/jbc.R100038200

52. Bourguignon LY, Wong G, Earle CA, Xia W. Interaction of low molecular weight hyaluronan with $\mathrm{CD} 44$ and toll-like receptors promotes the actin filament-associated protein 110-actin binding and MyD88-NFKB signaling leading to proinflammatory cytokine/chemokine production and breast tumor invasion. Cytoskeleton. (2011) 68:671-93. doi: 10.1002/cm.20544

53. Bartel DP. MicroRNAs: genomics, biogenesis, mechanism, and function. Cell. (2004) 116:281-97. doi: 10.1016/S0092-8674(04)00045-5

54. Bueno MJ, Gómez de Cedrón M, Laresgoiti U, Fernández-Piqueras J, Zubiaga AM, Malumbres M. Multiple E2F-induced microRNAs prevent replicative stress in response to mitogenic signaling. Mol Cell Biol. (2010) 30:2983-95. doi: 10.1128/MCB.01372-09

55. Jansson MD, Lund AH. MicroRNA and cancer. Mol Oncol. (2012) 6:590-610. doi: 10.1016/j.molonc.2012.09.006

56. Weber B, Stresemann C, Brueckner B, Lyko F. Methylation of human microRNA genes in normal and neoplastic cells. Cell Cycle. (2017) 6:1001-5. doi: $10.4161 /$ cc.6.9.4209

57. Volinia S, Calin GA, Liu CG, Ambs S, Cimmino A, Petrocca F, et al. A microRNA expression signature of human solid tumors defines cancer gene targets. Proc Natl Acad Sci USA. (2006) 103:2257-61. doi: $10.1073 /$ pnas. 0510565103

58. Li X, Yu X, He Y, Meng Y, Liang J, Huang L, et al. Integrated analysis of MicroRNA (miRNA) and mRNA profiles reveals reduced correlation between microrna and target gene in cancer. Biomed Res Int. (2018) 2018:1972606. doi: 10.1155/2018/1972606

59. Si ML, Zhu S, Wu H, Lu Z, Wu F, Mo YY. miR-21-mediated tumor growth. Oncogene. (2007) 26:2799-803. doi: 10.1038/sj.onc.1210083

60. Ma L, Reinhardt F, Pan E, Soutschek J, Bhat B, Marcusson EG, et al. Therapeutic silencing of miR-10b inhibits metastasis in a mouse mammary tumor model. Nat Biotechnol. (2010) 28:341-7. doi: 10.1038/nbt.1618

61. Lin SL, Chang DC, Lin CH, Ying SY, Leu D, Wu DT. Regulation of somatic cell reprogramming through inducible mir-302 expression. Nucleic Acids Res. (2011) 39: 1054-65. doi: 10.1093/nar/ gkq850

62. Asangani IA, Rasheed SA, Nikolova DA, Leupold JH, Colburn NH, Post S, et al. MicroRNA-21 (miR-21) post-transcriptionally downregulates tumor suppressor Pdcd4 and stimulates invasion, intravasation and metastasis in colorectal cancer. Oncogene. (2008) 27:2128-36. doi: 10.1038/sj.onc.12 10856
63. Wickramasinghe NS, Manavalan TT, Dougherty SM, Riggs KA, Li Y, Klinge CM. Estradiol downregulates miR-21 expression and increases miR-21 target gene expression in MCF-7 breast cancer cells. Nucleic Acids Res. (2009) 37:2584-95. doi: 10.1093/nar/gkp117

64. Xu LF, Wu, ZP, Chen Y, Zhu QS, Hamidi S, Navab R. MicroRNA-21 (miR21) regulates cellular proliferation, invasion, migration, and apoptosis by targeting PTEN, RECK, and Bcl-2 in lung squamous carcinoma. PLOS ONE. (2014) 9:e103698. doi: 10.1371/journal.pone.0103698

65. Bourguignon LY, Spevak CC, Wong G, Xia W, Gilad E. Hyaluronan-CD44 interaction with protein kinase $\mathrm{C} \epsilon$ promotes oncogenic signaling by the stem cell marker Nanog and the production of microRNA-21, leading to down-regulation of the tumor suppressor protein PDCD4, anti-apoptosis, and chemotherapy resistance in breast tumor cells. J Biol Chem. (2009) 284:26533-46. doi: 10.1074/jbc.M109.027466

66. Bourguignon LY, Earle C, Wong G, Spevak CC, Krueger K. Stem cell marker (Nanog) and Stat-3 signaling promote microRNA-21 expression and chemoresistance in hyaluronan/CD44-activated head and neck squamous cell carcinoma cells. Oncogene. (2012) 31:149-60. doi: 10.1038/onc.2011.222

67. Chen L, Bourguignon LY. Hyaluronan-CD44 interaction promotes cJun signaling and miRNA21 expression leading to $\mathrm{Bcl}-2$ expression and chemoresistance in breast cancer cells. Mol Cancer. (2014) 13:52. doi: 10.1186/1476-4598-13-52

68. Suzuki HI, Yamagata K, Sugimoto K, Iwamoto T, Kato S, Miyazono K. Modulation of microRNA processing by p53. Nature. (2009) 460:529-33. doi: $10.1038 /$ nature 08199

69. Davis BN, Hilyard AC, Lagna G, Hata A. SMAD proteins control DROSHA-mediated microRNA maturation. Nature. (2008) 454:56-61. doi: $10.1038 /$ nature 07086

70. Huang S. Regulation of metastases by signal transducer and activator of transcription 3 signaling pathway: clinical implications. Clin Cancer Res. (2007) 13:1362-6. doi: 10.1158/1078-0432.CCR-06-2313

71. Jiao X, Katiyar S, Willmarth NE, Liu M, Ma X, Flomenberg N, et al. c-Jun induces mammary epithelial cellular invasion and breast cancer stem cell expansion. J Biol Chem. (2010) 285:8218-26. doi: 10.1074/jbc.M110.100792

72. Wang J, Kuiatse I, Lee AV, Pan J, Giuliano A, Cui X. Sustained c-Jun-NH2-kinase activity promotes epithelial-mesenchymal transition, invasion, and survival of breast cancer cells by regulating extracellular signal-regulated kinase activation. Mol Cancer Res. (2010) 8:266-77. doi: 10.1158/1541-7786.MCR-09-0221

73. Kollmann K, Heller G, Sexl V. c-JUN prevents methylation of p16(INK4a) (and Cdk6): the villain turned bodyguard. Oncotarget. (2011) 2:422-7. doi: 10.18632 /oncotarget.279

74. Schreiber M, Kolbus A, Piu F, Szabowski A, Möhle-Steinlein U, Tian J, et al. Control of cell cycle progression by c-Jun is p53 dependent. Genes Dev. (1999) 13:607-19. doi: 10.1101/gad.13.5.607

75. Wisdom R, Johnson RS, Moore C. c-Jun regulates cell cycle progression and apoptosis by distinct mechanisms. EMBO J. (1999) 18:188-97. doi: 10.1093/emboj/18.1.188

76. Fujita S, Ito T, Mizutani T, Minoguchi S, Yamamichi N, Sakurai K, et al. miR-21 Gene expression triggered by AP-1 is sustained through a double-negative feedback mechanism. J Mol Biol. (2008) 378:492-504. doi: 10.1016/j.jmb.2008.03.015

77. Sasayama T, Nishihara M, Kondoh T, Hosoda K, Kohmura E. MicroRNA$10 \mathrm{~b}$ is overexpressed in malignant glioma and associated with tumor invasive factors, uPAR and RhoC. Int J Cancer. (2009) 125:1407-13. doi: $10.1002 / \mathrm{ijc} .24522$

78. Tian Y, Luo A, Cai Y, Su Q, Ding F, Chen H, et al. MicroRNA-10b promotes migration and invasion through KLF4 in human esophageal cancer cell lines. J Biol Chem. (2010) 285:7986-94. doi: 10.1074/jbc.M109.062877

79. Ma L, Teruya-Feldstein J, Weinberg RA. Tumour invasion and metastasis initiated by microRNA-10b in breast cancer. Nature. (2007) 449:682-8. doi: 10.1038 /nature 06174

80. Taher TE, Smit L, Griffioen AW, Schilder-Tol EJ, Borst J, Pals ST. Signaling through CD44 is mediated by tyrosine kinases. Association with p56lck in T lymphocytes. J Biol Chem. (1996) 271:2863-37. doi: 10.1074/jbc.271. 5.2863

81. Ilangumaran S, Briol A, Hoessli DC. CD44 selectively associates with active Src family protein tyrosine kinases Lck and Fyn in glycosphingolipid-rich 
plasma membrane domains of human peripheral blood lymphocytes. Blood. (1998) 91:3901-8.

82. Zhu D, Bourguignon LY. The ankyrin-binding domain of CD44s is involved in regulating hyaluronic acid-mediated functions and prostate tumor cell transformation. Cell Motil Cytoskeleton. (1998) 39:209-22. doi: 10.1002/ (SICI) 1097-0169(1998)39:3<209::AID-CM4>3.0.CO;2-\#

83. Yang J, Mani SA, Donaher JL, Ramaswamy S, Itzykson RA, Come C, et al. Twist, a master regulator of morphogenesis, plays an essential role in tumor metastasis. Cell. (2004) 117:927-399. doi: 10.1016/j.cell.2004.06.006

84. Yuen HF, Chan YP, Wong ML, Kwok WK, Chan KK, Lee PY, et al. Upregulation of Twist in oesophageal squamous cell carcinoma is associated with neoplastic transformation and distant metastasis. J Clin Pathol. (2007) 60:510-4. doi: 10.1136/jcp.2006.039099

85. Pham CG, Bubici C, Zazzeroni F, Knabb JR, Papa S, Kuntzen C, et al. Upregulation of Twist-1 by NF-kappaB blocks cytotoxicity induced by chemotherapeutic drugs. Mol Cell Biol. (2007) 27:3920-35. doi: 10.1128/MCB.01219-06

86. Vesuna F, Lisok A, Kimble B, Raman V. Twist modulates breast cancer stem cells by transcriptional regulation of CD24 expression. Neoplasia. (2009) 11:1318-28. doi: 10.1593/neo.91084

87. Cheng GZ, Chan J, Wang Q, Zhang W, Sun CD, Wang LH. Twist transcriptionally up-regulates AKT2 in breast cancer cells leading to increased migration, invasion, and resistance to paclitaxel. Cancer Res. (2007) 67:1979-87. doi: 10.1158/0008-5472.CAN-06-1479

88. Vesuna F, van Diest P, Chen JH, Raman V. Twist is a transcriptional repressor of E-cadherin gene expression in breast cancer. Biochem Biophys Res Commun. (2008) 367:235-41. doi: 10.1016/j.bbrc.2007.11.151

89. Bourguignon LY, Wong G, Earle C, Krueger K, Spevak CC. HyaluronanCD44 interaction promotes c-Src-mediated Twist signaling, microRNA$10 \mathrm{~b}$ expression, and RhoA/RhoC up-regulation, leading to Rho-kinaseassociated cytoskeleton activation and breast tumor cell invasion. J Biol Chem. (2010) 285:36721-35. doi: 10.1074/jbc.M110.162305

90. Shilatifard A. Chromatin modifications by methylation and ubiquitination: implications in the regulation of gene expression. Annu Rev Biochem. (2006) 75:243-69. doi: 10.1146/annurev.biochem.75.103004.142422

91. Ng HH, Feng Q, Wang H, Erdjument-Bromage H, Tempst P, Zhang Y, et al. Lysine methylation within the globular domain of histone H3 by Dot1 is important for telomeric silencing and Sir protein association. Genes Dev. (2002) 16:1518-27. doi: 10.1101/gad.1001502

92. van Leeuwen F, Gafken PR, Gottschling DE. Dotlp modulates silencing in yeast by methylation of the nucleosome core. Cell. (2002) 109:745-56. doi: 10.1016/S0092-8674(02)00759-6

93. Feng Q, Wang H, Ng HH, Erdjument-Bromage H, Tempst P, Struhl, et al. Methylation of H3-lysine 79 is mediated by a new family of HMTases without a SET domain. Curr Biol. (2002) 12:1052-8. doi: 10.1016/S0960-9822(02)00901-6

94. San-Segundo PA, Roeder GS. Role for the silencing protein Dot1 in meiotic checkpoint control. Mol Biol Cell. (2000) 11:3601-15. doi: 10.1091/mbc.11.10.3601

95. Bernt KM, Zhu N, Sinha AU, Vempati S, Faber J, Krivtsov AV, et al. MLL-rearranged leukemia is dependent on aberrant H3K79 methylation by DOT1L. Cancer Cell. (2011) 20:66-78. doi: 10.1016/j.ccr.2011.06.010

96. Kim W, Kim R, Park G, Park JW, Kim JE. Deficiency of H3K79 histone methyltransferase Dot1-like protein (DOT1L) inhibits cell proliferation. $J$ Biol Chem. (2012) 287:5588-99. doi: 10.1074/jbc.M111.328138

97. Janzen CJ, Hake SB, Lowell JE, Cross GA. Selective di- or trimethylation of histone H3 Lysine 76 by two DOT1 homologs is important for cell cycle regulation in Trypanosoma brucei. Mol Cell. (2006) 23:497-507. doi: 10.1016/j.molcel.2006.06.027

98. Liu H, Deng S, Zhao Z, Zhang H, Xiao J, Song W, et al. OCT4 regulates the miR-302 cluster in P19 mouse embryonic carcinoma cells. Mol Biol Rep. (2011) 38:2155-60. doi: 10.1007/s11033-010-0343-4

99. Lin SL, Chang DC, Chang-Lin S, Lin CH, Wu DT, Chen DT, et al. Mir-302 reprograms human skin cancer cells into a pluripotent ES-cell-like state. RNA. (2008) 14 : 2115-24. doi: 10.1261/rna.11 62708

100. Clay MR, Tabor M, Owen JH, Carey TE, Bradford CR, Wolf GT, et al. Singlemarker identification of head and neck squamous cell carcinoma cancer stem cells with aldehyde dehydrogenase. Head Neck. (2010) 32:1195-201. doi: 10.1002/hed.21315

101. Chen YC, Chen YW, Hsu HS, Tseng LM, Huang PI, Lu KH, et al. Aldehyde dehydrogenase 1 is a putative marker for cancer stem cells in head and neck squamous cancer. Biochem Biophys Res Commun. (2009) 385:307-13. doi: 10.1016/j.bbrc.2009.05.048

102. Ciccone DN, Su H, Hevi S, Gay F, Lei H, Bajko J, et al. KDM1B is a histone H3K4 demethylase required to establish maternal genomic imprints. Nature. (2009) 461:415-8. doi: 10.1038/nature08315

103. Wang J, Hevi S, Kurash JK, Lei H, Gay F, Bajko J, et al. The lysine demethylase LSD1 (KDM1) is required for maintenance of global DNA methylation. Nat Genet. (2009) 41:125-9. doi: 10.1038/ng.268

104. Mattick JS, Rinn JL. Discovery and annotation of long non-coding RNAs. Nat Struct Mol Biol. (2015) 22:5-7. doi: 10.1038/nsmb.2942

105. Mercer TR, Dinger ME, Mattick JS. Long non-coding RNAs: insights into functions. Nat Rev Genet. (2009) 10:155-9. doi: 10.1038/nrg2521

106. Prensner JR, Chinnaiyan AM. The emergence of lncRNAs in cancer biology. Cancer Discov. (2011) 1:391-407. doi: 10.1158/2159-8290.CD-11-0209

107. Gibb EA, Brown CJ, Lam WL. The functional role of long noncoding RNA in human carcinomas. Mol Cancer. (2011) 10:38. doi: 10.1186/1476-4598-10-38

108. Wang F, Li X, Xie X, Zhao L, Chen W. UCA1, a non-protein-coding RNA up-regulated in bladder carcinoma and embryo, influencing cell growth and promoting invasion. FEBS Lett. (2008) 582:1919-27. doi: 10.1016/j.febslet.2008.05.012

109. Fan Y, Shen B, Tan M, Mu X, Qin Y, Zhang F, et al. Long non-coding RNA UCA1 increases chemoresistance of bladder cancer cells by regulating Wnt signaling. FEBS J. (2014) 281:1750-8. doi: 10.1111/febs.12737

110. Huang J, Zhou N, Watabe K, Lu Z, Wu F, Xu M, et al. Long non-coding RNA UCA1 promotes breast tumor growth by suppression of p27 (Kip1). Cell Death Dis. (2014) 5:e1008. doi: 10.1038/cddis.2013.541

111. Han Y, Yang YN, Yuan HH, Zhang TT, Sui H, Wei XL, et al. UCA1, a long non-coding RNA up-regulated in colorectal cancer influences cell proliferation, apoptosis and cell cycle distribution. Pathology. (2014) 46:396401. doi: 10.1097/PAT.0000000000000125

112. Fan M, Li XY, Jiang W, Huang Y, Li JD, Wang ZM. A long non-coding RNA, PTCSC3, as a tumor suppressor and a target of miRNAs in thyroid cancer cells. Exp Ther Med. (2013) 5:1143-6. doi: 10.3892/etm.2013.933

113. Wang J, Liu X, Wu H, Ni P, Gu Z, Qiao Y, et al. CREB upregulates long noncoding RNA, HULC expression through interaction with microRNA-372 in liver cancer. Nucleic Acids Res. (2010) 38:5366-83. doi: 10.1093/nar/gkq285

114. Matouk IJ, Abbasi I, Hochberg A, Galun E, Dweik H, Akkawi M. Highly upregulated in liver cancer non-coding RNA is overexpressed in hepatic colorectal metastasis. Eur J GastroenHepat. (2009) 21:688-92. doi: 10.1097/MEG.0b013e328306a3a2

115. Du Y, Kong G, You X, Zhang S, Zhang T, Gao Y, et al. Elevation of highly upregulated in liver cancer (HULC) by hepatitis B virus X protein promotes hepatoma cell proliferation via down-regulating p18. J Biol Chem. (2012) 287:26302-11. doi: 10.1074/jbc.M112.342113

116. Panzitt K, Tschernatsch MMO, Guelly C, Moustafa T, Stradner M, Strohmaier HM, et al. Characterization of HULC, a novel gene with striking up-regulation in hepatocellular carcinoma, as non-coding RNA. Gastroenterology. (2007) 132:330-42. doi: 10.1053/j.gastro.2006. 08.026

117. Yildirim E, Kirby JE, Brown DE, Mercier FE, Sadreyev RI, Scadden DT, et al. Xist RNA is a potent suppressor of hematologic cancer in mice. Cell. (2013) 152:727-42. doi: 10.1016/j.cell.2013.01.034

118. Sirchia SM, Tabano S, Monti L, Recalcati MP, Gariboldi M, Grati FR, et al. Misbehaviour of XIST RNA in breast cancer cells. PLoS ONE. (2009) 4:e5559. doi: 10.1371/journal.pone.0005559

119. Hu Y, Wang J, Qian J, Kong X, Tang J, Wang Y, et al. Long non-coding RNA GAPLINC regulates CD44-dependent cell invasiveness and associates with poor prognosis of gastric cancer. Cancer Res. (2014) 74:6890-902. doi: 10.1158/0008-5472.CAN-14-0686

120. Lai MC, Yang Z, Zhou L, Zhu QQ, Xie HY, Zhang F, et al. Long non-coding RNA MALAT-1 overexpression predicts tumor recurrence of hepatocellular carcinoma after liver transplantation. Med Oncol. (2012) 29:1810-6. doi: 10.1007/s12032-011-0004-z 
121. Schmidt LH, Spieker T, Koschmieder S, Humberg J, Jungen D, Bulk $\mathrm{E}$, et al. The long non-coding MALAT-1 RNA indicates a poor prognosis in non-small cell lung cancer and induces migration and tumor growth. J Thorac Oncol. (2011) 6:1984-92. doi: 10.1097/JTO.0b013e318 2307 eac

122. Xu CA, Yang MH, Tian J, Wang XY, Li ZG. MALAT-1: a long noncoding RNA and its important 3' end functional motif in colorectal cancer metastasis. Int J Oncol. (2011) 39:169-75. doi: 10.3892/ijo.2011.1007

123. Zhang J, Zhang B, Wang T, Wang H. LncRNA MALAT1 overexpression is an unfavorable prognostic factor in human cancer: evidence from a meta-analysis. Int J Clin Exp Med. (2015) 8:5499-505.

124. Gupta RA, Shah N, Wang KC, Kim J, Horlings HM, Wong DJ, et al. Long non-coding RNA HOTAIR reprograms chromatin state to promote cancer metastasis. Nature. (2010) 464:1071-6. doi: 10.1038/nature08975

125. Kogo R, Shimamura T, Mimori K, Kawahara K, Imoto S, Sudo T, et al. Long non-coding RNA HOTAIR regulates polycomb-dependent chromatin modification and is associated with poor prognosis in colorectal cancers. Cancer Res. (2011) 71:6320-6. doi: 10.1158/0008-5472.CAN11-1021

126. Yang Z, Zhou L, Wu LM, Lai MC, Xie HY, Zhang F, et al. Overexpression of long non-coding RNA HOTAIR predicts tumor recurrence in hepatocellular carcinoma patients following liver transplantation. Ann Surg Oncol. (2011) 18:1243-50. doi: 10.1245/s10434-011-1581-y

127. Geng YJ, Xie SL, Li Q, Ma J, Wang GY. Large intervening non-coding RNA HOTAIR is associated with hepatocellular carcinoma progression. J Int Med Res. (2011) 39:2119-28. doi: 10.1177/147323001103900608

128. Kim K, Jutooru I, Chadalapaka G, Johnson G, Frank J, Burghardt $\mathrm{R}$, et al. HOTAIR is a negative prognostic factor and exhibits prooncogenic activity in pancreatic cancer. Oncogene. (2013) 32:1616-25. doi: 10.1038/onc.2012.193

129. Niinuma T, Suzuki H, Nojima M, Nosho K, Yamamoto H, Takamaru $\mathrm{H}$, et al. Upregulation of miR-196a and HOTAIR drive malignant character in gastrointestinal stromal tumors. Cancer Res. (2012) 72:1126-36. doi: 10.1158/0008-5472.CAN-11-1803

130. Yap KL, Li SD, Munoz-Cabello AM, Raguz S, Zeng L, Mujtaba S, et al. Molecular interplay of the non-coding RNA ANRIL and methylated histone H3 Lysine 27 by polycomb CBX7 in transcriptional silencing of INK4a. Mol Cell. (2010) 38:662-74. doi: 10.1016/j.molcel.2010.03.021

131. Chung SY, Nakagawa H, Uemura M, Piao L, Ashikawa K, Hosono $\mathrm{N}$, et al. Association of a novel long non-coding RNA in 8q24 with prostate cancer susceptibility. Cancer Sci. (2011) 102:245-52. doi: 10.1111/j.1349-7006.2010.01737.x

132. Nakano S, Murakami K, Meguro M, Soejima H, Higashimoto K, Urano $\mathrm{T}$, et al. Expression profile of LIT1/KCNQ1OT1 and epigenetic status at the KvDMR1 in colorectal cancers. Cancer Sci. (2006) 97:1147-54. doi: 10.1111/j.1349-7006.2006.00305.x

133. Matouk IJ, DeGroot N, Mezan S, Ayesh S, Abu-Iail R, Hochberg A, et al. The H19 non-coding RNA is essential for human tumor growth. PLoS ONE. (2007) 2:e845. doi: 10.1371/journal.pone.0000845

134. Wu W, Zhang S, Li X, Xue M, Cao S, Chen W. Ets-2 regulates cell apoptosis via the Akt pathway, through the regulation of urothelial cancer associated 1 , a long non-coding RNA, in bladder cancer cells. PLoS ONE. (2013) 8:e73920. doi: 10.1371/journal.pone.0073920

135. Xue M, Li X, Wu W, Zhang S, Wu S, Li Z, et al. Upregulation of long noncoding RNA urothelial carcinoma associated 1 by CCAAT/enhancer binding protein $\alpha$ contributes to bladder cancer cell growth and reduced apoptosis. Oncol Rep. (2014) 31:1993-2000. doi: 10.3892/or.2014.3092

136. Xue M, Li X, Li Z, Chen W. Urothelial carcinoma associated 1 is a hypoxiainducible factor- $1 \alpha$-targeted long non-coding RNA that enhances hypoxic bladder cancer cell proliferation, migration, and invasion. Tumour Biol. (2014) 35:6901-12. doi: 10.1007/s13277-014-1925-x

137. Lee JJ, Kim M, Kim HP. Epigenetic regulation of long non-coding RNA UCA1 by SATB1 in breast cancer. BMB Rep. (2016) 49:578-83. doi: 10.5483/BMBRep.2016.49.10.156

138. Hiemer SE, Szymaniak AD, Varelas $\mathrm{X}$. The transcriptional regulators TAZ and YAP direct transforming growth factor $\beta$-induced tumorigenic phenotypes in breast cancer cells. J Biol Chem. (2014) 289:13461-74. doi: 10.1074/jbc.M113.529115
139. Kumar PP, Emechebe U, Smith R, Franklin S, Moore B, Yandell M, et al. Coordinated control of senescence by IncRNA and a novel Tbox3 co-repressor complex. Elife. (2014) 3:e02805. doi: 10.7554/eLife. 02805

140. Chen S, Shao C, Xu M, Ji J, Xie Y, Lei Y, et al. Macrophage infiltration promotes invasiveness of breast cancer cells via activating long non-coding RNA UCA1. Int J Clin Exp Pathol. (2015) 8:9052-61.

141. Leslie EM, Deeley RC, Cole SP. Multidrug resistance proteins: role of Pglycoprotein, MRP1, MRP2, and BCRP (ABCG2) in tissue defense. Toxicol Appl Pharmacol. (2005) 204:216-37. doi: 10.1016/j.taap.2004.10.012

142. Shiga H, Rasmussen AA, Johnston PG, Langmacher M, Baylor A, Lee $M$, et al. Prognostic value of c-erbB2 and other markers in patients treated with chemotherapy for recurrent head and neck cancer. Head Neck. (2000) 22:599-608. doi: 10.1002/1097-0347(200009)22:6<599::AIDHED9>3.0.CO;2-M

143. Kato T, Duffey DC, Ondrey FG, Dong G, Chen Z, Cook JA, et al. Cisplatin and radiation sensitivity in human head and neck squamous carcinomas are independently modulated by glutathione and transcription factor NF-KB. Head Neck. (2000) 22:748-59. doi: 10.1002/10970347(200012)22:8<748::AID-HED2>3.0.CO;2-6

144. Bradford CR, Zhu S, Ogawa H, Ogawa T, Ubell M, Narayan A, et al. p53 mutation correlates with cisplatin sensitivity in head and neck squamous cell carcinoma lines. Head Neck. (2003) 25:654-61. doi: 10.1002/hed.10274

145. Hunter AM, LaCasse EC, Korneluk RG. The inhibitors of apoptosis (IAPs) as cancer targets. Apoptosis. (2007) 12:1543-68. doi: 10.1007/s10495-007-0087-3

146. Gyrd-Hansen M, Meier P. IAPs: from caspase inhibitors to modulators of NF-kB, inflammation and cancer. Nat Rev Cancer. (2010) 10:561-74. doi: $10.1038 / \mathrm{nrc} 2889$

147. Bourguignon LY, Xia W, Wong G. Hyaluronan-mediated CD44 interaction with p300 and SIRT1 regulates $\beta$-catenin signaling and NFKB-specific transcription activity leading to MDR1 and Bcl-xL gene expression and chemoresistance in breast tumor cells. J Biol Chem. (2009) 284:2657-71. doi: 10.1074/jbc.M806708200

148. Wang F, Zhou J, Xie X, Hu J, Chen L, Hu Q, et al. Involvement of SRPK1 in cisplatin resistance related to long non-coding RNA UCA1 in human ovarian cancer cells. Neoplasma. (2015) 62:432-8. doi: 10.4149/neo_2015_051

149. Wang X, Yang B, Ma B. The UCA1/miR-204/Sirt1 axis modulates docetaxel sensitivity of prostate cancer cells. Cancer Chemother Pharmacol. (2016) 78:1025-31. doi: 10.1007/s00280-016-3158-8

150. Bian Z, Jin L, Zhang J, Yin Y, Quan C, Hu Y, et al. LncRNA-UCA1 enhances cell proliferation and 5-fluorouracil resistance in colorectal cancer by inhibiting miR-204-5p. Sci Rep. (2016) 6:23892. doi: 10.1038/srep23892

151. Xu CG, Yang MF, Ren YQ, Wu CH, Wang LQ. Exosomes mediated transfer of lncRNA UCA1 results in increased tamoxifen resistance in breast cancer cells. Eur Rev Med Pharmacol Sci. (2016) 20:4362-8.

152. Li X, Wu Y, Liu A, Tang X. Long non-coding RNA UCA1 enhances tamoxifen resistance in breast cancer cells through a miR-18aHIF1 $\alpha$ feedback regulatory loop. Tumour Biol. (2016) 37:14733-43. doi: 10.1007/s13277-016-5348-8

153. Xiao $\mathrm{Y}$, Jiao $\mathrm{C}$, Lin $\mathrm{Y}$, Chen $\mathrm{M}$, Zhang J, Wang J, et al. IncRNA UCA1 contributes to imatinib resistance by acting as a ceRNA against miR-16 in chronic myeloid leukemia cells. DNA Cell Biol. (2017) 36:18-25. doi: 10.1089/dna.2016.3533

154. Pan J, Li X, Wu W, Xue M, Hou H, Zhai W, et al. Long non-coding RNA UCA1 promotes cisplatin/gemcitabine resistance through CREB modulating miR-196a-5p in bladder cancer cells. Cancer Lett. (2016) 382:6476. doi: 10.1016/j.canlet.2016.08.015

155. Zhang L, Cao X, Zhang L, Zhang X, Sheng H, Tao K. UCA1 overexpression predicts clinical outcome of patients with ovarian cancer receiving adjuvant chemotherapy. Cancer Chemother Pharmacol. (2016) 77:629-34. doi: 10.1007/s00280-016-2963-4

156. Wu C, Luo J. Long non-coding RNA (lncRNA) urothelial carcinomaassociated 1 (UCA1) enhances tamoxifen resistance in breast cancer cells via inhibiting mTOR signaling pathway. Med Sci Monit. (2016) 22:3860-7. doi: 10.12659/MSM.900689

157. Liu H, Wang G, Yang L, Qu J, Yang Z, Zhou X. Knockdown of long noncoding RNA UCA1 increases the tamoxifen sensitivity of breast cancer 
cells through inhibition of Wnt/ $\beta$-catenin pathway. PLoS ONE. (2016) 11:e0168406. doi: 10.1371/journal.pone.0168406

158. Cheng N, Cai W, Ren S, Li X, Wang Q, Pan H, Zhao M, et al. Long noncoding RNA UCA1 induces non-T790M acquired resistance to EGFR-TKIs by activating the AKT/mTOR pathway in EGFR-mutant non-small cell lung cancer. Oncotarget. (2015) 6:23582-93. doi: 10.18632/oncotarget.4361

159. Fang Q, Chen X, Zhi X. Long non-coding RNA (LncRNA) urothelial carcinoma associated 1 (UCA1) increases multi-drug resistance of gastric cancer via downregulating miR- 27b. Med Sci Monit. (2016) 22:3506-13. doi: 10.12659/MSM.900688

160. Shang C, Guo Y, Zhang J, Huang B. Silence of long non-coding RNA UCA1 inhibits malignant proliferation and chemotherapy resistance to adriamycin in gastric cancer. Cancer Chemother Pharmacol. (2016) 77:10617. doi: $10.1007 / \mathrm{s} 00280-016-3029-3$

161. Li J, Li Q, Chen L, Gao Y, Zhou B, Li J. Competitive endogenous RNA networks: integrated analysis of non-coding RNA and mRNA expression profiles in infantile hemangioma. Oncotarget. (2018) 9:11948-63. doi: 10.18632/oncotarget.23946

162. Wang F, Ying HQ, He BS, Pan YQ, Deng QW, Sun HL, et al. Upregulated IncRNA-UCA1 contributes to progression of hepatocellular carcinoma through inhibition of miR-216b and activation of FGFR1/ERK signaling pathway. Oncotarget. (2015) 6: 7899-917. doi: 10.18632/oncotarget.3219

163. Nie W, Ge HJ, Yang XQ, Sun X, Huang H, Tao X, et al. LncRNA-UCA1 exerts oncogenic functions in non-small cell lung cancer by targeting miR-193a-3p. Cancer Lett. (2016) 371:99. doi: 10.1016/j.canlet.2015.11.024

164. Xue M, Pang H, Li X, Li H, Pan J, Chen W. Long non-coding RNA urothelial cancer-associated 1 promotes bladder cancer cell migration and invasion by way of the hsa-miR-145-ZEB1/2-FSCN1 pathway. Cancer Sci. (2016) 107:18-27. doi: $10.1111 /$ cas.12844

165. Li R, Zhu H, Yang D, Xia J, Zheng Z. Long non-coding RNA IncBRM promotes proliferation and invasion of colorectal cancer by sponging miR204-3p and upregulating TPT1. Biochem Biophys Res Commun. (2019) 508:1259-63. doi: 10.1016/j.bbrc.2018.12.053
166. Jiao C, Song Z, Chen J, Zhong J, Cai W, Tian S, et al. IncRNA-UCA1 enhances cell proliferation through functioning as a ceRNA of Sox4 in esophageal cancer. Oncol Rep. (2016) 36:2960-6. doi: 10.3892/or.2016.5121

167. Sun MD, Zheng YQ, Wang LP, Zhao HT, Yang S. Long non-coding RNA UCA1 promotes cell proliferation, migration and invasion of human leukemia cells via sponging miR-126. Eur Rev Med Pharmacol Sci. (2018) 22:2233-45. doi: 10.26355/eurrev_201804_14809

168. Xu C, Sha Y, Xia T, Yang Y, Dai J, Luo L, et al. IncRNA-AC130710 targeting by miR-129-5p is upregulated in gastric cancer and associates with poor prognosis. Tumor Biol. (2014) 35:9701-6. doi: 10.1007/s13277-014-2274-5

169. Liu Q, Li Y, Lv W, Zhang G, Tian X, Li X, et al. UCA1 promotes cell proliferation and invasion and inhibits apoptosis through regulation of the miR129-SOX4 pathway in renal cell carcinoma. OncoTargets Therapy. (2018) 11:2475-87. doi: 10.2147/OTT.S1 60192

170. Cui SY, Wang R, Chen LB. MicroRNA-145: a potent tumour suppressor that regulates multiple cellular pathways. J Cell Mol Med. (2014) 18:1913-26. doi: $10.1111 /$ jcmm. 12358

171. Zeinali T, Mansoori B, Mohammadi A, Baradaran B. Regulatory mechanisms of miR-145 expression and the importance of its function in cancer metastasis. Biomed Pharmacother. (2019) 109:195-207. doi: 10.1016/j.biopha.2018.10.037

Conflict of Interest Statement: The author declares that the research was conducted in the absence of any commercial or financial relationships that could be construed as a potential conflict of interest.

Copyright $\odot 2019$ Bourguignon. This is an open-access article distributed under the terms of the Creative Commons Attribution License (CC BY). The use, distribution or reproduction in other forums is permitted, provided the original author(s) and the copyright owner(s) are credited and that the original publication in this journal is cited, in accordance with accepted academic practice. No use, distribution or reproduction is permitted which does not comply with these terms. 